\title{
Topographic and ecologic controls on root reinforcement
}

\author{
T. C. Hales, ${ }^{1,2}$ C. R. Ford, ${ }^{3}$ T. Hwang, ${ }^{1}$ J. M. Vose, ${ }^{3}$ and L. E. Band ${ }^{1}$ \\ Received 1 October 2008; revised 12 May 2009; accepted 2 June 2009; published 25 August 2009.
}

[1] Shallow landslides are a significant hazard in steep, soil-mantled landscapes. During intense rainfall events, the distribution of shallow landslides is controlled by variations in landscape gradient, the frictional and cohesive properties of soil and roots, and the subsurface hydrologic response. While gradients can be estimated from digital elevation models, information on soil and root properties remains sparse. We investigated whether geomorphically controlled variations in ecology affect the spatial distribution of root cohesion by measuring the distribution and tensile strength of roots from soil pits dug downslope of 15 native trees in the southern Appalachian Mountains, North Carolina, United States. Root tensile strengths from different hardwood tree species were similar and consistently higher than the only native shrub species measured (Rhododendron maximum). Roots were stronger in trees found on noses (areas of divergent topography) relative to those in hollows (unchanneled, convergent topography) coincident with the variability in cellulose content. This cellulose variability is likely related to topographic differences in soil water potential. For all species, roots were concentrated close to the soil surface, with roots in hollows being more evenly distributed in the soil column than those on noses. Trees located on noses had higher mean root cohesion than those in hollows because of a higher root tensile force. $R$. maximum had the shallowest, weakest roots suggesting that recent expansion of this species due to fire suppression has likely lowered the root cohesion of some hollows. Quantification of this feedback between physiologic controls on root growth and slope hydrology has allowed us to create a curvature-based model of root cohesion that is a significant improvement on current models that assume a spatially averaged value.

Citation: Hales, T. C., C. R. Ford, T. Hwang, J. M. Vose, and L. E. Band (2009), Topographic and ecologic controls on root reinforcement, J. Geophys. Res., 114, F03013, doi:10.1029/2008JF001168.

\section{Introduction}

[2] Shallow landslides and resulting debris flows create a significant human and infrastructural hazard in soil-mantled landscapes [Mills et al., 2003; Wieczorek et al., 2004] and are a key link between hillslope erosion and channel processes [Stock et al., 2005]. Debris flows usually initiate in topographic hollows, where soils are relatively thick and shallow groundwater flow causes high pore pressures [Montgomery and Dietrich, 1994; Pack et al., 1998]. Local precipitation, slope hydrology, gradient, soil thickness, and the spatial distribution of resistance from the cohesive and frictional properties of soil and vegetation modify the extent of landsliding related to any single precipitation event [Buchanan and Savigny, 1990; Iverson et al., 1997; Schmidt et al., 2001]. Many of these properties, such as shallow

\footnotetext{
${ }^{1}$ Department of Geography, University of North Carolina at Chapel Hill, Chapel Hill, North Carolina, USA.

${ }^{2}$ Currently at the School of Earth and Ocean Sciences, Cardiff University, Cardiff, UK.

${ }^{3}$ Coweeta Hydrologic Laboratory, Southern Research Station, USDA Forest Service, Otto, North Carolina, USA.
}

Copyright 2009 by the American Geophysical Union. 0148-0227/09/2008JF001168 subsurface hydrology and soil thickness are controlled by geomorphic and biotic processes. The topography of zerothorder drainage basins can also create systematic variability in forest species composition [Hack and Goodlett, 1960] suggesting that a similar trend in root reinforcement may exist at the hillslope scale.

[3] The magnitude of root reinforcement is dependent on the tensile strength and distribution of roots in the soil column [Waldron, 1977; Wu et al., 1979]. Roots are frictionally coupled to the surrounding soil and contribute to soil shear resistance [Bischetti et al., 2005; O'Loughlin and Ziemer, 1982; Reubens et al., 2007; Roering et al., 2003; Schmidt et al., 2001; Waldron, 1977; Watson et al., 1999; Wu, 1984a, 1984b; Wu et al., 1979; Ziemer, 1981]. The apparent cohesion provided by roots varies between 3 and $150 \mathrm{kPa}$ [Bischetti et al., 2005; De Baets et al., 2008; Genet et al., 2005; Gerber, 2004; Pollen and Simon, 2005; Schmidt et al., 2001 ] and can represent up to $100 \%$ of the cohesive strength of hillslope soils [Abernethy and Rutherfurd, 2001]. Root cohesion has been shown, through in situ shear testing [Wu et al., 1988a; Ziemer, 1981], to be dependent on the distribution and tensile force of roots. Root strength has often been highlighted as the key factor controlling cohesion as it decreases significantly with root decay, increasing landslide hazard in managed forests [Amaranthus et al., 1985; Brown 
and Krygier, 1971; Montgomery et al., 2000; O'Loughlin and Ziemer, 1982; Schmidt et al., 2001; Watson et al., 1999].

[4] While the role of roots in providing cohesive strength to soils is a well studied phenomenon, the aspects of plant physiology that control the magnitude of root reinforcement are poorly understood. Both the resistance of a root to tensile stress and the distribution of roots within a soil column are likely to be affected by plant responses to differences in climate and soil properties [Hathaway and Penny, 1975; Jackson et al., 1996]. The resistance of a root to tension may be controlled by cellulose, which forms as a long chain polymer in the cell walls of root xylem tissue [Genet et al., 2005]. The only major study of the relationship between cellulose and root strength showed that a decrease in tensile strength correlated with a decrease in the relative cellulose content [Genet et al., 2005]. This correlation suggests that there is a physiological link between root strength and cellulose content. Understanding the environmental conditions that control the distribution of cellulose may allow us to understand the mechanisms that control root reinforcement.

[5] Variations in root cohesion related to vertical root distributions have received less study despite a wealth of distribution data available in the literature [Jackson et al., 1996; Stone and Kalisz, 1991, and references therein]. These studies suggest that, in general, a surprisingly consistent exponential decay in the density and number of roots with soil depth exists across many different geographic locations and climates. Vertical root distributions vary primarily as a function of biome (e.g., temperate forest and desert) and plant functional group (grasses, shrubs, and trees) [Jackson et al., 1996]. Temperate coniferous forests (and deserts) contain some of the deepest rooting plants [Stone and Kalisz, 1991], and forest ecosystems in general have the highest root biomass $\left(2-5 \mathrm{~kg} \mathrm{~m}^{-2}\right)$ [Jackson et al., 1996]. It is important to note that these studies focused on biome-scale differences in root distributions, and much less information is available on the variability of root distributions within a biome in response to landscape-level geomorphic and hydrologic conditions. Locally, while the general exponential decay still holds, the vertical distribution of roots also depends on the tree species, the presence of barriers to root growth in a soil column (such as a bedrock or saprolite), and water content [Kochenderfer, 1973; McGinty, 1976; Sakai et al., 2007].

[6] Local topographic, climatic, and pedologic factors influence plant species distributions across the landscape [Hack and Goodlett, 1960] and may affect key root properties, such as root strength and hydraulic architecture [Addington et al., 2006]. Some of the important parameters controlling the distribution of roots (e.g., soil depth and soil moisture content) can be estimated using combinations of soil landscape models and distributed hydrologic models [e.g., Dietrich et al., 1995; Tague and Band, 2004], yet most models of slope stability require field-intensive empirical data to constrain root cohesion. Root cohesion is at sensitive parameter in these models and one of the most difficult to quantify [Wooten et al., 2007]; empirical treatment of this parameter may lead to large errors in estimates of slope stability. A systematic understanding of the relationships between topography and rooting dynamics would help refine current models of slope stability.

[7] This paper describes a field experiment designed to understand how topographic position affects the distribution and strength of roots in a debris flow-prone landscape. Our objectives were to (1) characterize variations in root tensile strength among species and across topographic positions, (2) examine the importance of root cellulose in regulating root tensile strength among species and topographic positions, and (3) determine the importance of vertical root distribution in determining soil stability. Finally, we synthesized these data to produce a spatial model of root cohesion based on the distribution of curvature in a landscape.

\section{Methods}

\subsection{Field Location}

[8] The Coweeta basin is located in the southern Appalachian Mountains, United States (Figure 1). It has been a United States Forest Service experimental forest since 1935 and part of the Long-Term Ecological Research network since 1980 (http://coweeta.ecology.uga.edu). Precipitation in the catchment is characterized by frequent, small, low-intensity rainfall events and rare large storms. Average annual rainfall ranges from $1800 \mathrm{~mm}$ at low elevations $(\sim 700 \mathrm{~m})$ to $2300 \mathrm{~mm}$ at high elevations $(\sim 1600 \mathrm{~m})$ [Swift et al., 1988]. Most of the recorded high rainfall events occur in autumn and have been associated with tropical storms [Swift et al., 1988]. Large landslide and flooding events tend to coincide with these hurricane or tropical storm impacts. Three major landsliding events, in 1940, 1969, and 2004, were related to hurricanes. The 1940 event was caused by two storms which generated $74 \mathrm{~cm}$ of cumulative precipitation in three days [Witt, 2005], caused 200-300 debris flows, and resulted in 30-40 casualties and over $\$ 30$ million in damage [Clark, 1987; Wieczorek et al., 2004; Witt, 2005]. The 1969 event generated $71 \mathrm{~cm}$ of rain in $8 \mathrm{~h}$, caused over 3700 debris flows, and resulted in 150 casualties and $\$ 116$ million in damage [Morgan et al., 1999]. In 2004, over 73 landslides initiated during two hurricanes [Latham et al., 2005; Witt, 2005] and caused debris flow activity in the Coweeta basin on Watershed 36 [Witt, 2005].

[9] Historic vegetation patterns in Coweeta have been influenced by human activity, primarily through both clearcut and selective logging, the introduction of chestnut blight (Cryphonectria parasitica), and fire management [Douglass and Hoover, 1988; R. A. Hertzler, History of the Coweeta experimental forest, unpublished report, U.S. Department of Agriculture Forest Service, Otto, North Carolina, 1936]. Most human activity has focused on valley floors, which has little impact on debris flow triggering, yet the use of fire in managing upland forests is an essential control on the distribution of vegetation and therefore root strength [Witt, 2005]. Native Americans used fire as a tool to keep forests open to allow for easier hunting and gathering [Douglass and Hoover, 1988]. When Europeans populated this area, the regular fire disturbance was suppressed and many of the steepest slopes were heavily logged (Hertzler, unpublished report, 1936). More recently, virtually all mature Castanea dentata (American chestnut) trees were eliminated by chestnut blight [Elliott and Hewitt, 1997]. Fire suppression in most of the southern Appalachians has lead to the expansion of fire-sensitive species such as Rhododendron maximum (rosebay rhododendron) and Kalmia latifolia (mountain laurel) [Phillips and Murdy, 1985]. The resulting forests in the Coweeta basin are relatively mature ( $\sim 85$ years old $)$ 


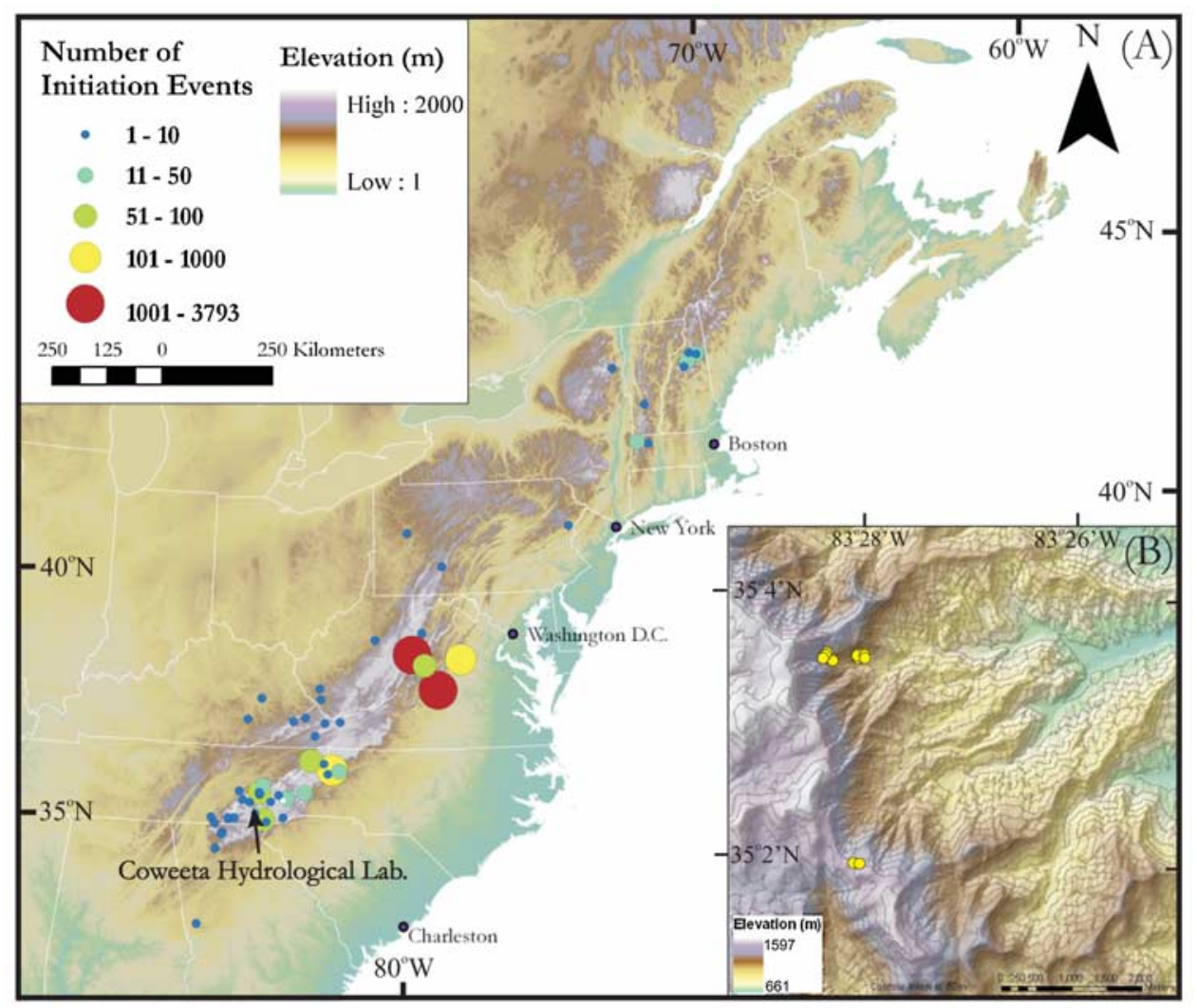

Figure 1. (a) Map of the eastern United States showing the location and size of historic debris flow events (based on Clark [1987] and Witt [2005]). Our study area, the Coweeta Hydrological Laboratory, is located in the southern Appalachians. (b) A topographic map of our study area showing the locations of pit and trench excavations. Contour interval is $50 \mathrm{~m}$.

Oak-Hickory and Northern Hardwood forests (at higher elevations) with an increasing component of fire-intolerant species [Elliott and Swank, 2008].

\subsection{Pit and Trench Locations}

[10] We manually excavated 15 soil pits in Watershed 36 (at elevations between $1053 \mathrm{~m}$ and $1284 \mathrm{~m}$ ), which was selectively logged in 1919, removing all trees with a diameter at breast height (DBH) greater than $38 \mathrm{~cm}$ (Hertzler, unpublished report, 1936). Nine pits were excavated in a hollow close to the basin outlet and four pits were excavated higher in Watershed 36 (Figure 1b). Pits were located on both noses (areas of convex upward topography), on side slopes (areas of planar topography), and in hollows (areas of concave upward topography). Identification of the topographic position was primarily made in the field and confirmed by placing accurate global positioning systems measurements of pit locations onto a curvature map derived from the North Carolina LiDAR data set (a $7 \mathrm{~m}$ resolution data set available from the North Carolina flood mapping program; http://www.ncfloodmaps.com). Soils were part of the Edneyville-Chestnut, Cullsaja-Tuckaseegee, and Cleveland-Chestnut-Rock Outcrop complexes, which are all sandy-silty loam inceptisols, with relatively thin A horizons, undifferentiated $\mathrm{B}$ horizons and varying percentages of coarse colluvial material. Pits were dug with horizontal dimensions of approximately 100 by $150 \mathrm{~cm}$, with depth varying between 120 and $180 \mathrm{~cm}$ because of differences in depths to saprolite.

[11] We located pits adjacent to and downslope from several major hardwood species found within the OakHickory and Northern Hardwoods forest associations. The species we sampled were sugar maple (Acer saccharum, 1 pit), eastern hemlock (Tsuga canadensis, 1 pit), rosebay rhododendron (Rhododendron maximum, 2 pits), northern red oak (Quercus rubra, 3 pits), black birch (Betula lenta, 1 pit), tulip poplar (Liriodendron tulipifera, 3 pits), hickory (Carya sp, 1 pit.), red maple (Acer rubrum, 1 pit), chestnut oak (Quercus prinus, 1 pit), and black oak (Quercus velutina, 1 pit). All pits were located within $80 \mathrm{~cm}$ of the plant of interest. Pit locations were chosen on the basis of topographic position and adjacent tree characteristics (size, age, species, and relative isolation). We sampled trees that were relatively isolated from others to minimize the possibility of roots from other species being included intersecting the front face of the pit. We sampled woody roots, which reduces possible contamination from herbaceous understory shrubs, but were not able to distinguish roots from different tree species on the basis of field interpretation of morphology. Despite our best efforts to choose isolated plants, the lateral extent of plant roots can be considerable [Stone and Kalisz, 1991] and it is likely that some roots from other species that were close to the each pit were included in the measurements of root distributions. For several species ( $R$. maximum, $Q$. rubra, and L. tulipifera), we dug multiple pits in different 
Table 1a. Soil Shear Strength Measurements Derived by Vane Shear in Pits Dug in Coweeta Soils

\begin{tabular}{cccc}
\hline $\begin{array}{c}\text { Pit/Trench } \\
\text { Number }\end{array}$ & Species & Location & $\begin{array}{r}\text { Soil Shear Strength } \\
\left(\mathrm{kg} \mathrm{cm}^{-2}\right)\end{array}$ \\
\hline 1 & A. saccharum & Nose & 0.18 \\
6 & Q. rubra & Nose & 0.20 \\
9 & Q. velutina & Hollow & 0.21 \\
10 & Q. rubra & Hollow & 0.13 \\
11 & Q. rubra & Nose & 0.22 \\
13 & B. lenta & Hollow & 0.19 \\
14 & L. tulipifera & Hollow & 0.21 \\
15 & L. tulipifera & Nose & 0.26 \\
\hline
\end{tabular}

topographic positions (i.e., noses and hollows). For any species, these pits were $<50 \mathrm{~m}$ apart from each other. Roots were sampled in May and early June during a drought period, no rainfall occurred during the sampling period.

[12] In addition to the pits, we used a backhoe to excavate two trenches, up to $3 \mathrm{~m}$ wide and $1.5 \mathrm{~m}$ deep, in Watershed 28, which has a different treatment history compared to Watershed 36, where 77 ha of the watershed were commercially clear-cut and 39 ha of cove forest was thinned. Trenches are distinguished from pits because they are larger and at least $1 \mathrm{~m}$ from the surrounding trees, suggesting that they represent an average rooting distribution for the forest in that area. Trenches were located in $\sim 40$-year-old stands of the Northern Hardwood forest type.

\subsection{Soil Properties}

[13] We quantified soil shear strength using vane shear measurements ( $5 \mathrm{~cm}$ diameter) at $25 \mathrm{~cm}$ intervals from the surface to the base of pits $1,6,9,10,11,13,14$, and 15 (Table 1a). Five root-free measurements were made at each interval. For pits 14 (L. tulipifera) and 13 (B. lenta), and our mixed species trench location (located in a hollow) we collected three Shelby tube samples, oriented vertically, sampling the soil between 10 and $40 \mathrm{~cm}$ depth, for triaxial shear strength testing at the North Carolina Department of Transportation soil testing facility in Raleigh, North Carolina. Consolidated undrained triaxial tests were conducted at a confining pressure of $34.5 \mathrm{kPa}$. We calculated soil friction angle and cohesion for each of our locations using the stress path, maximum deviator stress, and maximum principal stress ratio methods (Table 1b).

\subsection{Root Distributions}

[14] We determined the vertical distribution (from surface to saprolite) of roots from all pits using image analysis
[Abernethy and Rutherfurd, 2001]. The size and distribution of roots within each pit were quantified by painting roots within a $40 \mathrm{~cm}$ wide vertical swath that intersected the front face of the pit wall (closest to the plant of interest). Painting roots improved the accuracy of our measurements relative to using unpainted roots. We created a map of roots that intersected the vertical pit wall by cutting each root as close to the face as possible. We then photographed the pit wall and imported the photographs into a digitising program (Golden Software's Didger). Each photograph was rectified using tie points designated by measuring tapes in both the vertical and horizontal directions in the pit. We estimated the diameter of each root by drawing a line across the root and measuring its length. The exported data contained information about both the location and overbark diameter of the root. Spatial resolution of the positions of the roots was $1 \mathrm{~cm}$. Diameters were measured with an error of $0.05 \mathrm{~mm}$, reflecting errors are due to the optical properties of the camera. Roots that were oriented at an oblique angle to the main face had an elliptical cross section that was measured along its minor axis.

\subsection{Root Strength Measurements}

[15] We measured the tensile strengths of roots from each of our 15 pits using the methodology of Schmidt et al. [2001] and Gerber [2004]. Tensile strengths were measured in the field on recently cut, healthy roots, which were clamped to a spring scale and pulled until failure. Spring scales (measuring up to $20 \mathrm{~kg}$ ) were used in place of more sophisticated clamping and measurement systems because of field limitations. Field-based measurements were made by cutting roots from the main face of the pit, clamping them using a commercially available crocodile clamp (http://www. pesola.com) and pulling them by hand with as consistent force as possible until they failed. This field methodology is consistent with others employed in field studies [Pollen and Simon, 2005; Schmidt et al., 2001] and while displacement rate is not as well controlled as is possible in laboratory experimentation [Cofie and Koolen, 2001] this method allowed us to collect large samples in difficult field conditions. Healthy roots were primarily defined on the basis of bark characteristics. The bark of unhealthy roots appeared thickened and weak. Because of the significant weakening with root death [Gerber, 2004; Schmidt et al., 2001] we considered healthy roots most likely to contribute strength to the soil column. For roots $<1 \mathrm{~mm}$ diameter, it was difficult to distinguish the bark, which resulted in difficulty in distinguishing the health of the root. For each pit, we sampled at least 150 roots, that were between 5 and $10 \mathrm{~cm}$ in length

Table 1b. Result of Cohesive Strength and Friction Angle Measurements Made Using Unconsolidated Undrained Triaxial Measurements at $34.5 \mathrm{kPa}$ Confining Pressure in Pits Dug in Coweeta Soils ${ }^{\mathrm{a}}$

\begin{tabular}{|c|c|c|c|c|c|c|c|}
\hline \multirow[b]{2}{*}{$\begin{array}{l}\text { Pit/Trench } \\
\text { Number }\end{array}$} & \multirow[b]{2}{*}{ Consolidation } & \multicolumn{2}{|c|}{ Stress Path } & \multicolumn{2}{|c|}{ Maximum Deviator Stress } & \multicolumn{2}{|c|}{$\begin{array}{c}\text { Maximum Principle } \\
\text { Stress Ratio }\end{array}$} \\
\hline & & $\begin{array}{c}\text { Mean } c_{s} \\
(\mathrm{kPa})\end{array}$ & Mean $\phi$ & $\begin{array}{c}\text { Mean } c_{s} \\
(\mathrm{kPa})\end{array}$ & Mean $\phi$ & $\begin{array}{c}\text { Mean } c_{S} \\
(\mathrm{kPa})\end{array}$ & Mean $\phi$ \\
\hline 13 & Normal/light over & 0 & 30 & 0 & 33 & 0 & 34 \\
\hline 14 & Normal/light over & 0 & 35.4 & 0 & 38 & 0 & 39 \\
\hline HT & Normal/light over & 4 & 30 & 1 & 37 & 1 & 38 \\
\hline
\end{tabular}

${ }^{\mathrm{a}}$ Here $c_{s}$ is cohesive strength and $\phi$ is the friction angle. 
and with an overbark diameter range of 0.06-4.35 mm. Our data are somewhat biased toward smaller root diameters because of the relatively small number of larger $(>2 \mathrm{~mm})$ roots encountered in each pit. Occasional premature failure of large roots was related to the clamping method used for this study (henceforth referred to as a clamp failure), in which roots were clamped at a single point, resulting in deformation of the root fibers, a common problem with using this method to determine root tensile strength (even with specially designed clamping systems [Bischetti et al., 2005]).

[16] Root tensile force measurements are usually related to the distribution of root diameter via regression analysis [Schmidt et al., 2001]. Because of the importance of larger roots in the regression analysis used to define the strength versus diameter curves for each location, we compared data sets of roots that included only roots that failed in the middle of the root with a data set that included clamp failures. Our sensitivity analysis showed that while the spread of data was larger when clamp failures were included, the significance of the line was increased because of the larger sample size on larger diameter roots, so these data are included in our regression analysis. Roots occasionally failed at joints in the rooting structure rather than in the center of a root segment. Although this measurement is reflective of the strength of the junction rather than the root itself, we included these data as roots have been observed to fail at junctions during landslide initiation.

\subsection{Cellulose Measurements}

[17] To determine the relationship between root tensile strength and root cellulose content for roots of varying diameter we sampled roots from $Q$. rubra and L. tulipifera across five pits. We sampled additional 55-60 roots from each pit, beyond the initial sampling of 150 roots described above; this represented a balance between sampling a wide range of root diameters and having sufficient root biomass for cellulose determination. On each root sample, we determined tensile force at failure (described above). On the failed root fragment, we removed all side roots and cut the fragment to a representative length (typically $<5 \mathrm{~cm}$ for the finer categories and $<15 \mathrm{~cm}$ for the coarser categories, see below). We measured the outside diameter in two locations along the fragment, proximal and distal to the failure junction using calipers accurate to $0.01 \mathrm{~mm}$. All root fragments were individually cleaned of soil material in ca. $25^{\circ} \mathrm{C}$ deionized water with a small brush, dried to a constant mass at $65^{\circ} \mathrm{C}$ and weighed to $0.0001 \mathrm{mg}$ accuracy. All root fragments were grouped into one of four diameter classes: very fine $(<0.5 \mathrm{~mm})$, fine $(0.5-1 \mathrm{~mm})$, medium $(1-2 \mathrm{~mm})$, coarse $(>2 \mathrm{~mm})$. Roots were then ground to a fine powder $(8000-\mathrm{D}$, SPEX CertiPrep, Inc.), sealed into a $30 \mu \mathrm{m}$ nitrogen-free polyester digestion pouch (Ankom Technology Corp.), and weighed to $0.001 \mathrm{mg}$ accuracy.

[18] We modified the procedure described by Leavitt and Danzer [1993] to extract root cellulose. Briefly the extraction involved three steps: extraction of waxes, oils and resins in a soxhlet apparatus, boiling to remove hydrophilic compounds, and bleaching of the inorganic salts and low molecular weight polysaccharides (including lignin, gums and starches). Samples were placed in a soxhlet apparatus containing $250 \mathrm{ml}$ toluene and $125 \mathrm{ml}$ ethanol, kept at a steady boil, and extracted for $44 \mathrm{~h}$. After cooling, this process was repeated up to five times (until the flushed solution ran clear) using only $400 \mathrm{ml} 100 \%$ ethanol with no toluene. Cooled samples were then transferred to a boiling water bath $(700 \mathrm{ml}$ reverse osmosis (RO) water) for $6 \mathrm{~h}$. Samples were rinsed in an agitated RO water bath for $30 \mathrm{~min}$. Rinsing was repeated six times, replacing the RO water each time. Finally, samples were agitated in a solution containing $800 \mathrm{ml}$ of distilled water, $8 \mathrm{~g}$ of sodium chlorite $\left(\mathrm{NaClO}_{2}\right)$, and $4 \mathrm{ml}$ of glacial acetic acid $\left(100 \% \mathrm{C}_{2} \mathrm{H}_{4} \mathrm{O}_{2}\right)$ that was kept at $70-75^{\circ} \mathrm{C}$. The reaction and reaction environment $(\mathrm{pH}<4.0)$ were maintained by adding sodium chlorite, glacial acetic acid, and water as needed. The reaction was considered complete when the $\mathrm{pH}$ did not increase over a $12 \mathrm{~h}$ period. Samples were then rinsed in an agitated RO water bath for $30 \mathrm{~min}$. Rinsing was repeated six times, replacing the RO water each time. Samples were dried to a constant mass at $65^{\circ} \mathrm{C}$ and weighed to $0.001 \mathrm{mg}$ accuracy. Percent cellulose content was calculated as the postextraction dry mass divided by the preextraction dry mass $\left(\%, \mathrm{mg} \mathrm{mg}^{-1}\right)$.

\subsection{Root Cohesion Calculations}

[19] The total amount of root cohesive strength within a soil column is dependent on the number, size, and tensile strengths of the roots within a specific soil mass [Pollen and Simon, 2005; Schmidt et al., 2001; Wu et al., 1979, 1988b]. The tensile strength of an individual root $\left(t_{\mathrm{ri}}\right)$ can be defined as

$$
t_{\mathrm{ri}}=\left[T_{\mathrm{ri}} / \pi\left(d_{\mathrm{ri}} / 2\right)^{2}\right]
$$

where $T_{\mathrm{ri}}$ is the tensile force of root $i$ at failure and $d_{\mathrm{ri}}$ is the diameter of root $i$ at the failure point [Schmidt et al., 2001; $W u$ et al., 1979]. This means that the total root tensile strength across the landslide failure plane $\left(t_{\mathrm{r}}\right)$ can be expressed as

$$
t_{r}=\sum_{i=1}^{n} t_{\mathrm{ri}}\left[\pi\left(d_{\mathrm{ri}} / 2\right)^{2} / A_{s}\right]=\left(\sum_{i=1}^{n} T_{\mathrm{ri}} / A_{s}\right)
$$

with $A_{\mathrm{s}}$ being the area of the failure plane and $n$ is the number of roots within $A_{\mathrm{s}}$ [Wu et al., 1988a, 1979]. This method (hereafter referred to as the $\mathrm{Wu}$ method) assumes that all of the roots in a specific area fail in unison and represents a maximum estimate of root cohesion.

[20] Conversion of the total root tensile strength into root cohesion for a landslide shear zone requires the geometry of the root relative to the shear zone at the point of failure to be taken into account. This means that shear of a root at angle $\alpha$, will be resolved into tangential $\left(t_{r}(\cos \alpha \tan \phi)\right)$ and normal $\left(t_{r}(\sin \alpha)\right)$ components

$$
c_{r}=t_{r}(\cos \alpha \tan \phi+\sin \alpha)
$$

Roots are brittle and plastic and recover most of their strain after failure $(>10 \%$ of the strain may be unrecoverable [Cofie and Koolen, 2001; Schmidt et al., 2001]), making it difficult to accurately measure the angle of shear in the field. 
Sensitivity analyses on in situ data has shown that both the normal and tangential components of shear can be approximated with the value 1.2 for $40^{\circ}<\alpha<70^{\circ}$ and $25^{\circ}<\phi<40^{\circ}$ [Wu et al., 1979]. For a lower friction angle $(\phi)$ of $16^{\circ}$ a value of 1 has been estimated for $43^{\circ}<\alpha<66^{\circ}$ by in situ shear box testing [Abernethy and Rutherfurd, 2001].

[21] An alternative to the $\mathrm{Wu}$ method, called a fiber bundle model (FBM), is derived from theory used to understand the breaking points of textile threads [Daniels, 1945]. The theory is relevant if a bundle of fibers of varying sizes (and strengths) is clamped and a tensile force applied incrementally, from zero until the breaking point of the bundle is reached. At very small tensile forces, the load is distributed across all $(n)$ fibers and equilibrium can be reached without any root breaking. As the applied load increases, eventually one of the weakest threads will break, resulting in the load being distributed over $n-1$ fibers. The resulting increase in load on the remaining fibers may cause other fibers to break, which causes further redistribution of load until either equilibrium is reached where the remaining fibers have sufficient strength to resist the tensile force or the whole bundle breaks [Daniels, 1945]. This methodology has been applied to the breakage of root bundle under the tensile forces applied during landslide initiation [Pollen and Simon, 2005]. In this case, the imposed tensile force is distributed across the root fibers in proportion to root area. This method is argued to produce predicted root cohesion values that are more consistent with failure criteria determined for river bank failures [Pollen et al., 2004].

[22] To determine the effects of differing root distributions on the average root cohesion, we used the $\mathrm{Wu}$ and FBM methods to calculate root cohesion for both the whole soil column and for each $10 \mathrm{~cm}$ depth interval in each pit. We used these two methods to bracket the true value of root cohesive strength. Root tensile force values were based on the diameter-force relationship for each pit in combination with the measured distribution of roots in the soil column.

\subsection{Statistical Methods}

[23] We tested hypotheses regarding differences in measured parameters as a function of plant life form (shrubs versus trees) and topographic position. We used a repeated measure, mixed effects, nonlinear model (PROC NLMIXED, SAS v9.1, Cary, NC USA) to test the following four null hypotheses: (1) that parameter estimates for the pull force required for root failure $\left(T_{\mathrm{R}}\right)$ versus root cross-sectional area $\left(A_{\mathrm{R}}\right)$ were the same among shrub and tree life forms; (2) within the tree life form that parameter estimates for $T_{\mathrm{R}}$ versus $A_{\mathrm{R}}$ were the same between noses and hollows; (3) that parameter estimates for the cumulative frequency of roots $\left(N_{\mathrm{R}}\right)$ versus soil depth $(D)$ were the same among topographic positions; and (4) that parameter estimates for the root cohesive strength $\left(c_{\mathrm{R}}\right)$ versus $D$ were the same among topographic positions. Our model took the form

$$
y=f\left(x_{i j}, \beta, u_{i}\right)+e_{i j}
$$

where $f$ is a function of known vector covariates $\left(x_{\mathrm{ij}}\right)$; a vector of unknown fixed parameters $(\beta)$; and a vector of unknown random effect parameters $\left(u_{\mathrm{i}}\right)$, in our case, $u 0$ and $u 1$; and $e_{\mathrm{ij}}$ is unknown random errors [Peek et al., 2002]. For each of our four hypotheses, the nonlinear function took the form

$$
\begin{gathered}
T_{R}=\beta 0\left(1-e^{-\beta 1 A_{R}}\right), \\
N_{R}=\beta 2\left(e^{-\beta 3 D}\right), \\
c_{R}=\beta 4\left(e^{-\beta 5 D}\right) .
\end{gathered}
$$

Here $\beta 0$ represents the maximum pull force required before failure on the population of roots sampled. Here $\beta 1$ is a parameter that represents initial rate of increase in pull force required before failure with each unit root area. Here $\beta 2$ and $\beta 3$ represent the intercept and rate of decrease of the cumulative number of roots with depth, respectively. Here $\beta 4$ and $\beta 5$ represent the root cohesive strength at the soil surface and the rate of decrease in the root cohesive strength with each unit soil depth. We tested for significant differences between both parameters for both life forms and both topographic extremes using custom contrast statements. In the case of the cumulative root distribution with depth (equation (5b)), we expected the intercept to be similar for both topographic positions (i.e., both were expected to be $100 \%$ ); thus we tested for significant differences in the rate of decline in cumulative root frequency for each topographic position using custom contrast statements. For root cohesive strength measurements we compared relationships between methods of calculating root cohesive strength for either topographic position. If the upper and lower 95\% confidence interval for each parameter estimate did not overlap we interpreted this as a significant difference.

[24] We tested the hypothesis that tree root cellulose content did not vary between topographic extremes using a single-factor blocked ANOVA with root diameter category as a covariate (PROC GLM, SAS). Cellulose content data were transformed with an arcsine square root function prior to analysis due to lack of independence between the variance and mean in percentage data [Dowdy and Wearden, 1991]. Our experimental unit was soil pit, and because observations within a soil pit were not independent, we incorporated a blocking factor in the design. We report Type III statistics where appropriate.

\subsection{Spatial Root Cohesion Model}

[25] We created a simple spatial model of root cohesion for the Coweeta drainage basin by creating a map of curvature, calculated using the default ArcGIS fourth-order polynomial method [Moore et al., 1991], on the North Carolina LiDAR digital elevation model. We used a low-pass circular filter (radius of three pixels) to smooth the initial curvature data set. We then divided the landscape into areas of positive curvature (noses) and negative curvature (hollows) and assigned random root cohesion values for each pixel from a uniform distribution of values with limits derived from our mean root cohesion values calculated using the Wu method. We chose to use a uniform distribution as it is consistent with the method of assigning root cohesion in the SINMAP 

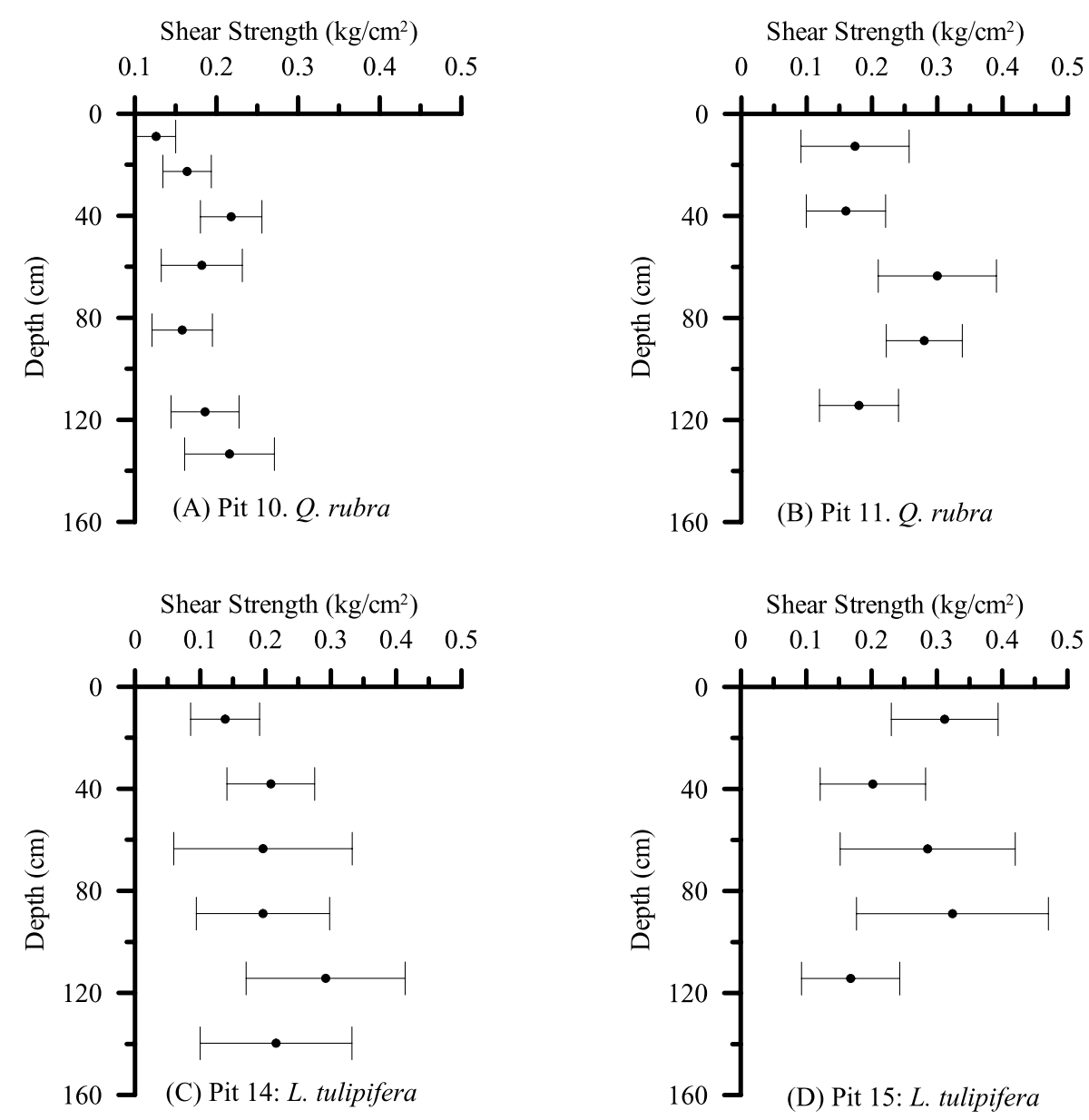

Figure 2. Depth distribution of shear strength measured using a vane shear in Q. rubra and L. tulipifera pits in both (a and c) hollow and (b and d) nose locations. Points represent the mean of five measurements and the bars are standard deviations.

slope stability model [Pack et al., 1998], although it has no physical basis.

\section{Results}

\subsection{Soil Characteristics}

[26] Soil vane shear measurements were highly variable with depth, and hence no trends were apparent (Figure 2). The large standard deviations (based on $n=5$ ) in our measurements reflect that the size of our vane was typically smaller than the size of weathered clasts in the soil $(5 \mathrm{~cm}$ vane width with clasts up to $10 \mathrm{~cm}$ width). There was no depth-dependent or horizon-dependent trend in shear strength. The large standard deviation in the measurements primarily reflects horizontal differences in grain size and clay content.

[27] All of our samples were normally to lightly overconsolidated, with effective soil cohesion between 0 and $1 \mathrm{kPa}$ (Table 1b). Effective soil friction angles measured using the stress path method (the preferred method for Appalachian soils [Lambe and Riad, 1990]) varied between $30^{\circ}$ and $35^{\circ}$. Friction angles measured using the maximum deviator stress and maximum principal stress methods were higher $\left(33^{\circ}-39^{\circ}\right)$.

\subsection{Vertical Distribution of Roots in the Soil Column}

[28] All topographic locations showed a characteristic exponential decay in the number of roots from the surface (Figure 3). Roots were common throughout the soil column, although typically only the fine root biomass was represented at depth. This does not suggest that larger roots are not found at depth; instead, it suggests that they are less likely to intersect with our pit face. For example, roots $>2 \mathrm{~mm}$ diameter represented less than $5 \%$ of the total number of roots in a soil column. Because pit faces were dominated by the fine root biomass, the mean diameter of roots typically remained constant with depth.

[29] The slope of the exponential distribution differed as a function of topographic position (Figure $3, F_{1,11}=91.21$, $P<0.0001$ ). Roots on noses tended to concentrate close to the surface and decrease to close to 0 below $40-50 \mathrm{~cm}$ soil depth (nose $\beta 3=3.49$ ). The number of roots remained low until the saprolite layer was reached, upon which a local increase in the number of roots was observed. In hollows, roots were also concentrated at the soil surface, but tended to remain in significant numbers down to ca. $90 \mathrm{~cm}$ deep in the soil column (hollow $\beta 3=3.02$ ). Unlike the nose locations, where the number of roots was consistently low below $50 \mathrm{~cm}$, the distribution of roots in the hollows was more variable, 


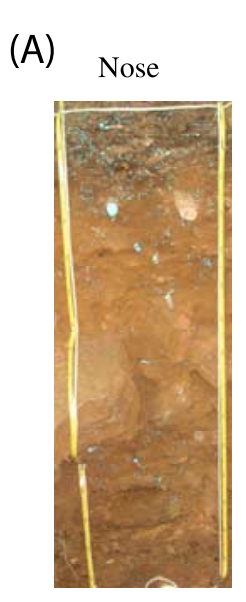

(B)

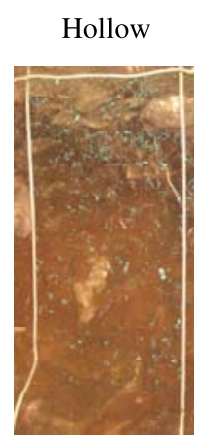

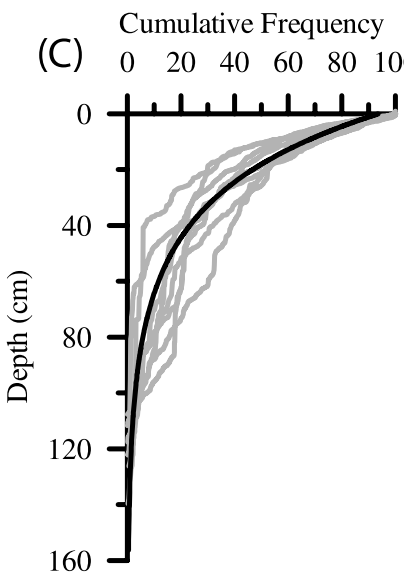

(D) Cumulative Frequency

(D) $\begin{array}{llllll}0 & 20 & 40 & 60 & 80 & 100\end{array}$

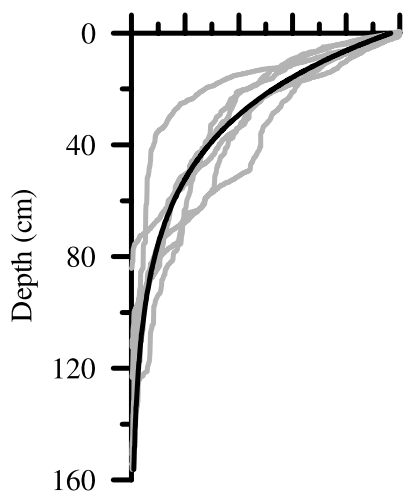

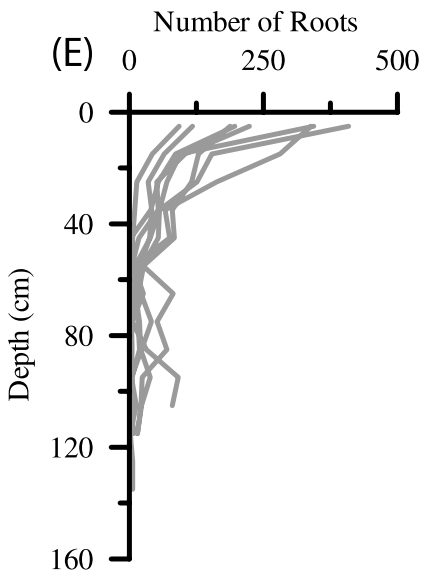

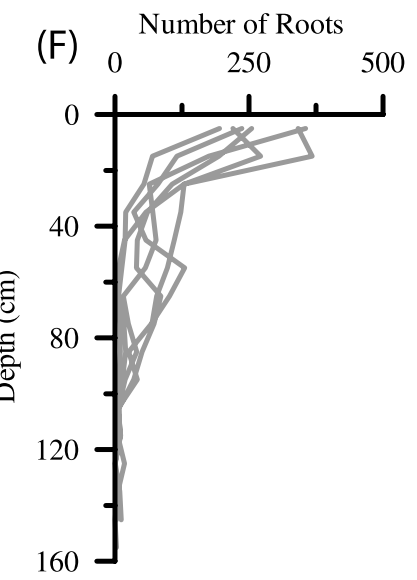

Figure 3. The distribution of roots as a function of soil depth for pits located on noses and in hollows. (c and d) The cumulative frequency of the number of roots as a function of depth, with gray lines representing individual pits, while black lines are the modeled mean of all pits (equation (5b)). (e and f) The absolute number of roots binned at every $10 \mathrm{~cm}$ depth interval, which provides an approximate measure of root area ratio. Gray lines are individual pits, while the black line is the mean of all pits. (a and b) Photographs are vertical sections of two Q. rubra pits (pits 10 and 11) dug within $20 \mathrm{~m}$ of each other. Note the difference in the depth of the dark A horizon between the two sites. Blue painted roots where used for analysis of root distributions.

with roots concentrated at different levels within the soil column.

\subsection{Variation in Root Tensile Force}

[30] In all pits and across all species, larger roots could support a greater force before failing compared to smaller roots (Figure 4). The force at failure increased as a function of root area described by a two-parameter exponential saturation model (equation (5a)). We present tensile force curves versus root area instead of the more commonly used tensile stress curves versus diameter (see auxiliary material) [Bischetti et al., 2005; Genet et al., 2005; Pollen and Simon, 2005] because of autocorrelation, as tensile stress is calculated using diameter (equation (1)). ${ }^{1}$ Despite a large sample size, the shape of the regression curves fit to the data depended strongly on the strengths of larger roots.

[31] There was little variation in root tensile force among species (Figure 4), although relationships between life forms

${ }^{1}$ Auxiliary materials are available in the HTML. doi:10.1029/ 2008JF001168. were significantly different. The curves for all species except A. saccharum and $R$. maximum overlapped. A. saccharum roots were sampled from a single pit on a ridge, and therefore may be anomalous. Roots from $R$. maximum, the only woody shrub sampled, had a significantly lower rate of increase in the tensile force required before failure per root area than the other species sampled $(\mathrm{F} 1,13=8.07, \mathrm{P}=0.014)$. For our sampled root population, trees and shrubs had similar maximum force at failure $(\mathrm{F} 1,13=0.08, \mathrm{P}=0.78)$.

[32] Within the tree life form, topographic location affected root tensile force (Figure 5). Tree roots extracted from nose locations had a significantly greater rate increase in the tensile force required before failure per root area those extracted from hollow locations $(\mathrm{F} 1,9=10.28, \mathrm{P}=0.011)$. For our sampled root population, trees from hollow and nose topographic positions had similar maximum force at failure $(\mathrm{F} 1,9=3.11, \mathrm{P}=0.12)$.

\subsection{Variation in Cellulose Content}

[33] Cellulose content of roots varied as a function of diameter and topographic position (Figure 5). These two 

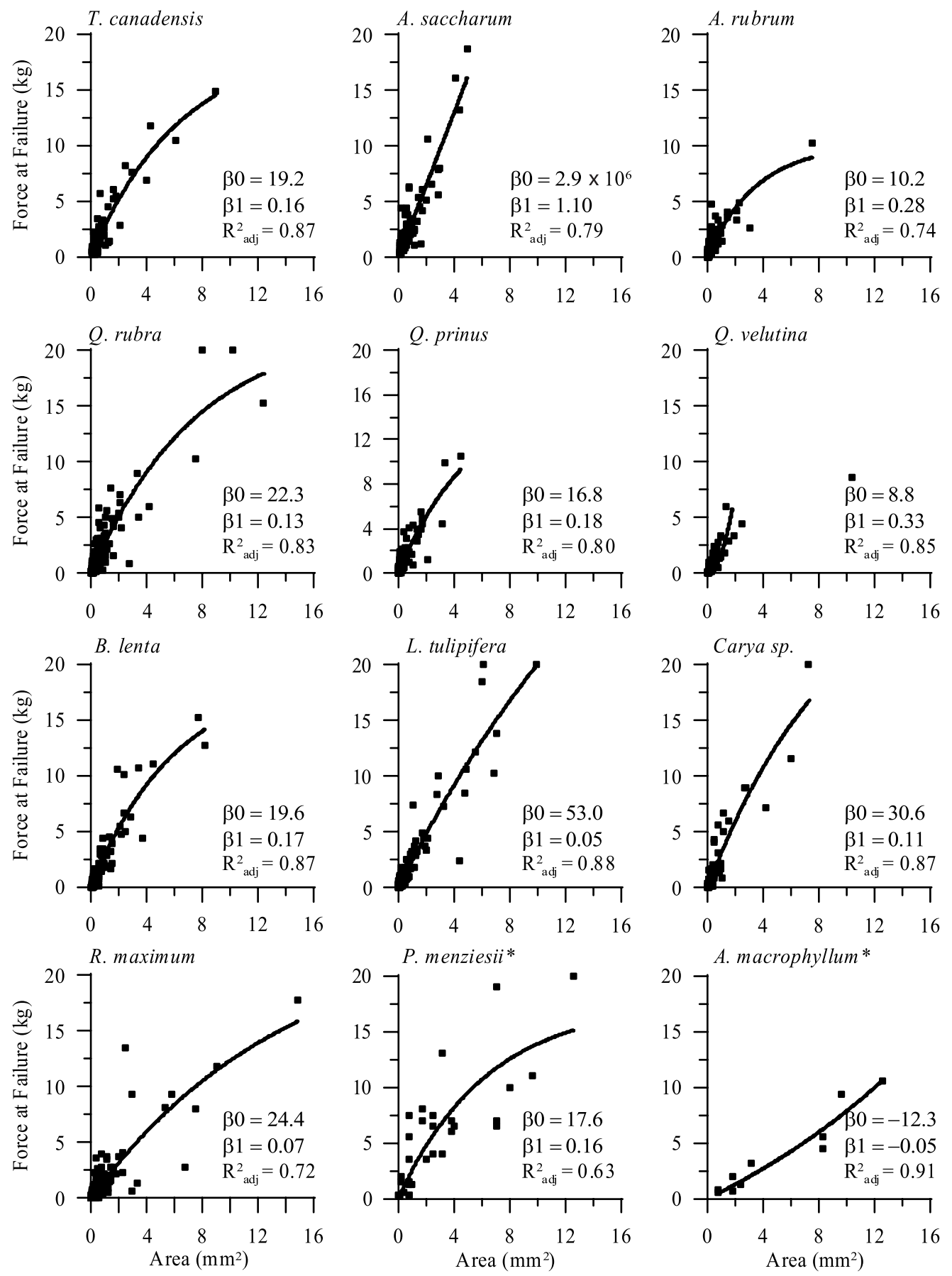

* Data from Schmidt et al (2001)

Figure 4. Root tensile force versus root cross-sectional area relationships for common southern Appalachian tree and woody shrub species. All graphs are shown with a best-fit regression line (equation (5a)) and an assessment of the variance of the data. We have compared our species (Tsuga canadensis, Acer saccharum, Acer rubrum, Quercus rubra, Quercus prinus, Quercus velutina, Betula lenta, Liriodendron tulipifera, Carya sp., and Rhododendron maximum) with two commonly occurring western United States species (Pseudotsuga menziesii and Acer macrophyllum) collected using the same technique by Schmidt et al. [2001]. Adjusted $R^{2}$ values were calculated as each sample contains a different number of roots [Zar, 1984].

factors explained much of the variation in our data, hence the overall model was significant $\left(F_{12,5}=5.77, P=0.03\right)$. Cellulose content decreased with increasing root diameter $\left(F_{3,5}=9.36, P=0.02\right)$. Up to $40 \%$ difference in relative cellulose content was found between very fine and larger root categories. Topographic position also significantly affected cellulose content $\left(F_{2,5}=5.85, P=0.05\right)$ as nose locations had consistently higher mean cellulose content than hollows. 

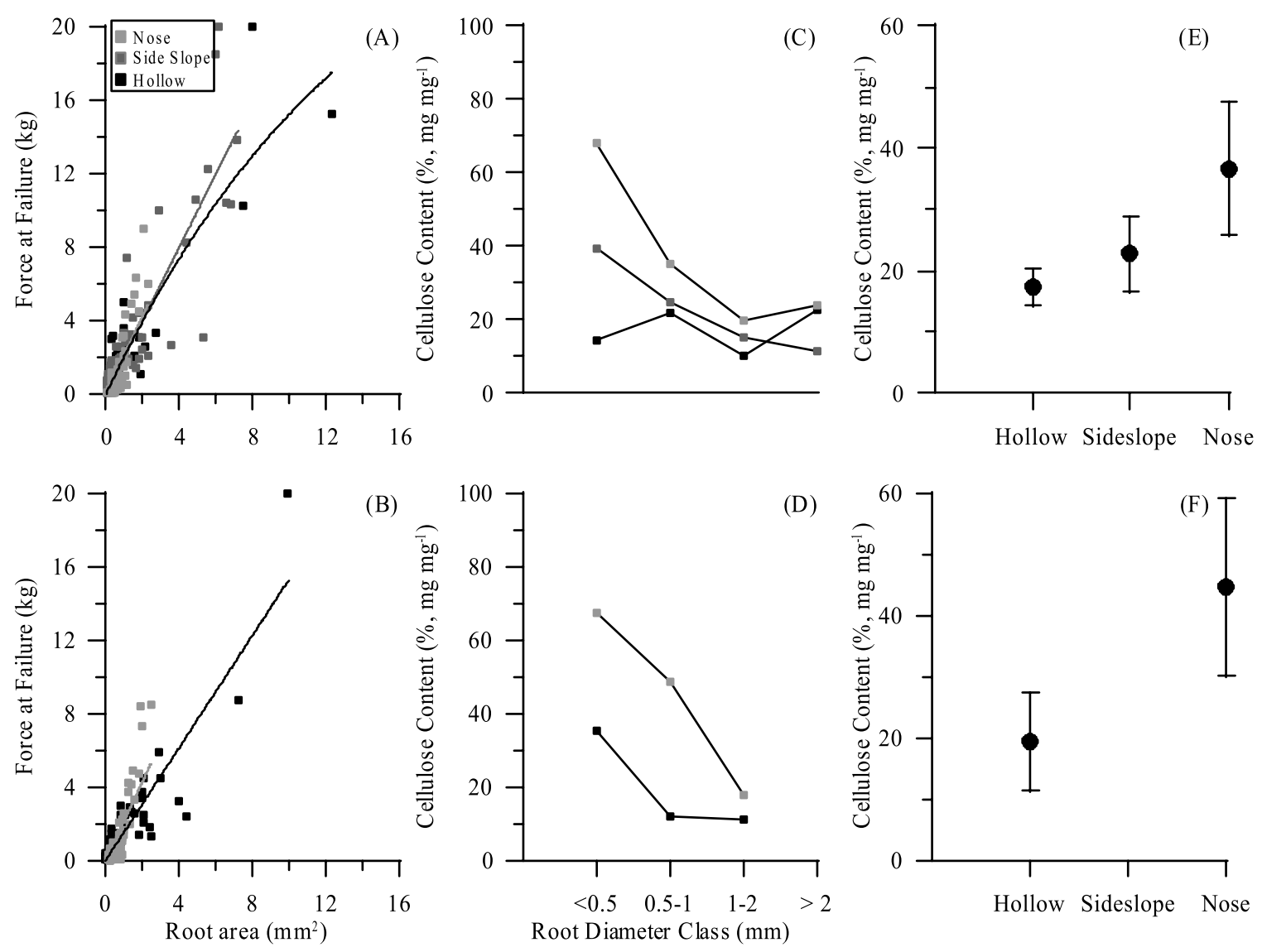

Figure 5. Topographic variability in root tensile force and cellulose contents. Root tensile forcediameter relationships for (a) nose, side slope, and hollow locations containing L. tulipifera and (b) nose and hollow locations containing Q. rubra. Variations in cellulose content for root diameter classes and topographic positions for (c) L. tulipifera and (d) Q. rubra. Mean cellulose content across all root diameter classes (bars denote standard error) as a function of topographic position for (e) L. tulipifera and (f) Q. rubra.

For both L. tulipifera and Q. rubra, very fine roots on noses had $>30 \%$ more cellulose than hollows. Although the cellulose content in fine roots appeared greater in nose positions compared to hollow positions, there was no significant interaction $\left(F_{6,5}=1.84, P=0.26\right)$. Because of the relatively short hillslope lengths, we only had one pit located on a side slope (defined as a planar hillslope found between noses and hollows), which appeared to have a mean cellulose content intermediate between the nose and hollow locations; however, because of a lack of replication we could not statistically evaluate this trend.

\subsection{Root Cohesion}

[34] When considering the root cohesive strength across the whole soil column, the mean root cohesion for all pits measured using the $\mathrm{Wu}$ method was $7.6 \pm 5.4 \mathrm{kPa}(1 \sigma)$, while the FBM method was considerably lower at $3.4 \pm$ $2.4 \mathrm{kPa}(1 \sigma)$ (Table 2). Mean root cohesions varied for nose (Wu method $10.5 \pm 7.7 \mathrm{kPa}(1 \sigma)$; FBM method $4.4 \pm$ $3.5 \mathrm{kPa}(1 \sigma)$, excluding low root count data) and hollow (Wu method $5.7 \pm 1.2 \mathrm{kPa}(1 \sigma)$; FBM method $2.8 \pm 0.9 \mathrm{kPa}$ $(1 \sigma))$ locations. Our minimum root cohesion values are more than double the values of soil cohesive strength, suggesting that root cohesion is a major control on slope stability in this region.
[35] The distribution of root cohesion in the soil differed significantly with topographic position; however, whether one or both parameter estimates varied with topographic position depended on the calculation method used (Figure 6). Using the Wu method, root cohesive strength just below the soil surface was significantly greater on noses compared to hollows (58.4 versus $\left.21.4 \mathrm{kPa}, F_{1,11}=31.30, P=0.0002\right)$. Noses also showed a more rapid decrease in root cohesion with depth compared to hollows (10.5 versus $5.0 \mathrm{kPa} \mathrm{m}^{-1}$, $\left.F_{1,11}=11.44, P=0.006\right)$, which primarily reflected the distribution of roots. With the FBM method, root cohesive strength just below the soil surface was also significantly greater on noses compared to hollows $(21.3$ versus $13.9 \mathrm{kPa}$, $\left.F_{1,11}=4.80, P=0.05\right)$. In contrast to the $\mathrm{Wu}$ method, however, the FBM method showed that noses and hollows have similar rates of decrease in root cohesion with depth (6.1 versus $\left.4.7 \mathrm{kPa} \mathrm{m}^{-1}, F_{1,11}=1.10, P=0.31\right)$. For hollows, the two methods gave similar results for the two parameter estimates: cohesive strength just below the soil surface as well as the rate of decrease in root cohesion with depth. In contrast, for noses, the two methods gave significantly different results for cohesive strength just below the soil surface but similar results for the rate of decrease in root cohesion with depth. 
Table 2. Vertically Integrated Root Cohesion Measurements for All Pits and Trenches Dug in Coweeta Hydrologic Laboratory ${ }^{\mathrm{a}}$

\begin{tabular}{|c|c|c|c|c|c|}
\hline $\begin{array}{l}\text { Pit Number } \\
\text { or Trench }\end{array}$ & Species & $\begin{array}{l}\text { Wu Root Cohesion } \\
(\mathrm{kPa})\end{array}$ & $\begin{array}{l}\text { FBM Root Cohesion } \\
(\mathrm{kPa})\end{array}$ & $\begin{array}{c}\text { Percent } \\
\text { Difference }\end{array}$ & Topography \\
\hline 3 & R. maximum & 3.42 & 1.66 & 49 & $\mathrm{H}$ \\
\hline 6 & Q. rubra & 6.52 & 2.71 & 42 & $\mathrm{H}$ \\
\hline 9 & Q. velutina & 5.31 & 2.72 & 51 & $\mathrm{H}$ \\
\hline 10 & $Q$ rubra & 6.76 & 3.39 & 50 & $\mathrm{H}$ \\
\hline 13 & B. lenta & 6.85 & 2.58 & 38 & $\mathrm{H}$ \\
\hline 14 & L. tulipifera & 5.02 & 1.91 & 38 & $\mathrm{H}$ \\
\hline $\mathrm{T}$ & Mixed & 6.02 & 4.38 & 73 & $\mathrm{H}$ \\
\hline 1 & A. saccharum & 22.38 & 11.02 & 49 & $\mathrm{~N}$ \\
\hline 2 & T. canadensis & 6.59 & 2.74 & 42 & $\mathrm{~N}$ \\
\hline 4 & Carya sp.* & 7.06 & 2.64 & 37 & $\mathrm{~N}$ \\
\hline 7 & A. rubrum & 3.78 & 2.19 & 58 & $\mathrm{~N}$ \\
\hline 8 & Q. prinus* & 3.82 & 1.87 & 49 & $\mathrm{~N}$ \\
\hline 11 & Q rubra & 10.62 & 3.80 & 36 & $\mathrm{~N}$ \\
\hline 12 & R. mахітит & 4.63 & 1.70 & 37 & $\mathrm{~N}$ \\
\hline 15 & L. tulipifera & 5.11 & 1.91 & 37 & $\mathrm{~N}$ \\
\hline $\mathrm{T}$ & Mixed & 20.04 & 7.57 & 38 & $\mathrm{~N}$ \\
\hline 5 & L. tulipifera* & 5.45 & 2.33 & 43 & $\mathrm{~S}$ \\
\hline $\begin{array}{l}\text { Mean (Standard } \\
\text { Deviation) }\end{array}$ & & $7.61(5.40)$ & $3.36(2.43)$ & & \\
\hline
\end{tabular}

${ }^{a}$ Topographic positions are noted as either hollow $(\mathrm{H})$, side slope $(\mathrm{S})$ or nose $(\mathrm{N})$. Mean and standard deviation across all species and locations given for each method. Percent difference denotes the difference between the FBM and Wu methods for determining root cohesion. Asterisks denote low root counts due to patchy light.

\subsection{Spatial Root Cohesion Model}

[36] Our model shows a strong bimodal distribution in hardwood root cohesion across Coweeta, with lower root cohesions concentrated in hollows. Use of a low-pass filter across these data has smoothed the distribution of low, hollow-based root cohesions into side slopes. The circular radius of three pixels was chosen to provide continuity across hollows and represents a maximum estimate of the hollow area, and therefore the area of low root cohesion. In nose areas, while individual pixels can have relatively low root cohesive strengths, these are often isolated areas, so may not produce landslides. When $R$. maximum values are included with this data set, then there is a large reduction in the hollow cohesion and a small reduction in the mean nose root cohesion (Figure 7). However, because $R$. maximum shrubs tend to overwhelm hollows once they are introduced, and because this shrub is not ubiquitous throughout Appalachian hardwood forests our random model contains only hardwoods. We consider this discrete model with uniform species to be a first generation approximation of root cohesion patterns. A more complex, continuous approximation would include estimates of $R$. maximum and other stand species information, which may be derived from a combination of remote sensing and empirical sampling [e.g., Bolstad et al., 2001].

\section{Discussion}

\subsection{Effects of Soil Structure on Root Strength}

[37] The total amount of water in a soil column is modulated by the local soil water holding capacity and the transmissivity and topographic position of the soil. The local hydraulic properties are primarily related to the grain size, frequency of roots, and soil composition [Selby, 1993]. Soils that we sampled in hollows were more colluvial with thick A horizons, undifferentiated B horizons and no saprolite to $1.2 \mathrm{~m}$ depth. In contrast, soils on ridges tended to be more differentiated, with thin A horizons, a strongly weathered B horizon, and a thick saprolite layer $(>1 \mathrm{~m})$.

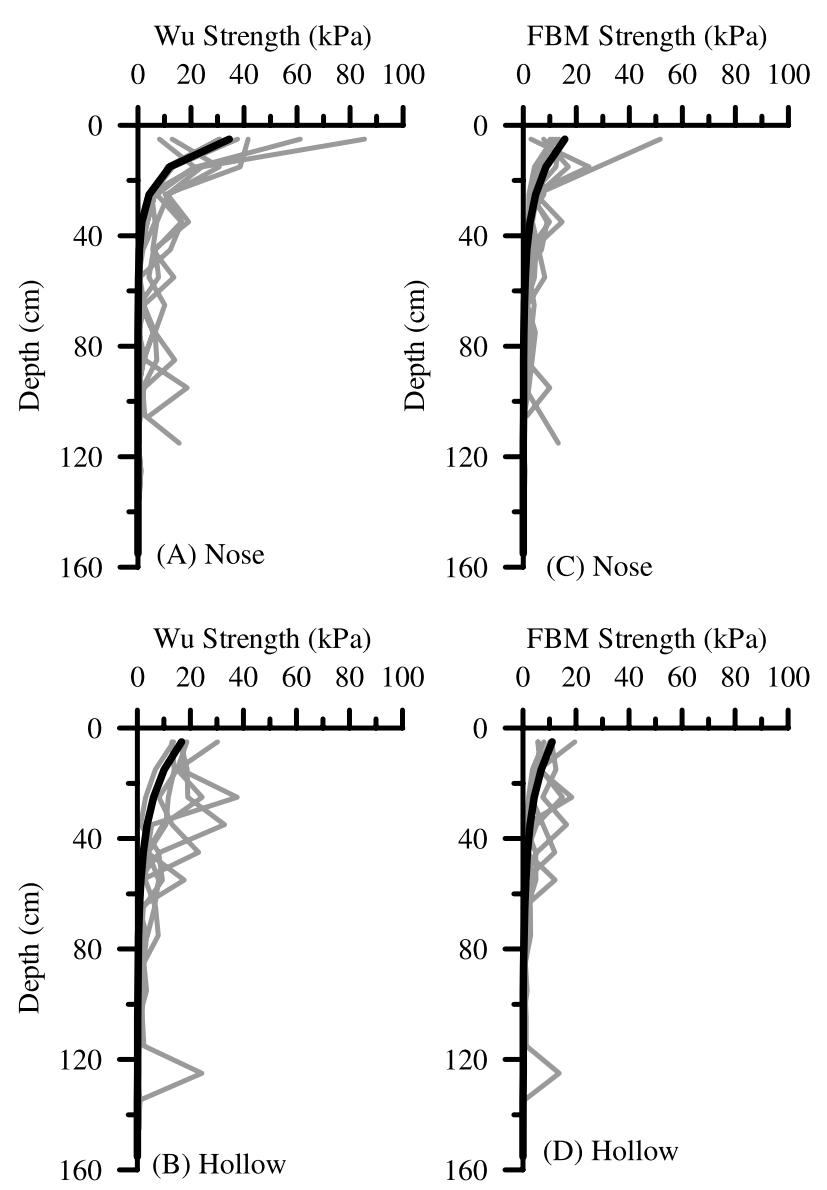

Figure 6. Distribution of root cohesive strength as a function of depth for (a and c) nose and (b and d) hollow locations using the $\mathrm{Wu}$ method (Figures 6a and 6b) [Wu et al., 1979] and fiber bundle model method (Figures $6 \mathrm{c}$ and 6d) [Pollen and Simon, 2005]. Individual gray lines correspond to pits, while the dark line corresponds to the modeled mean across pits (equation (5c)). 


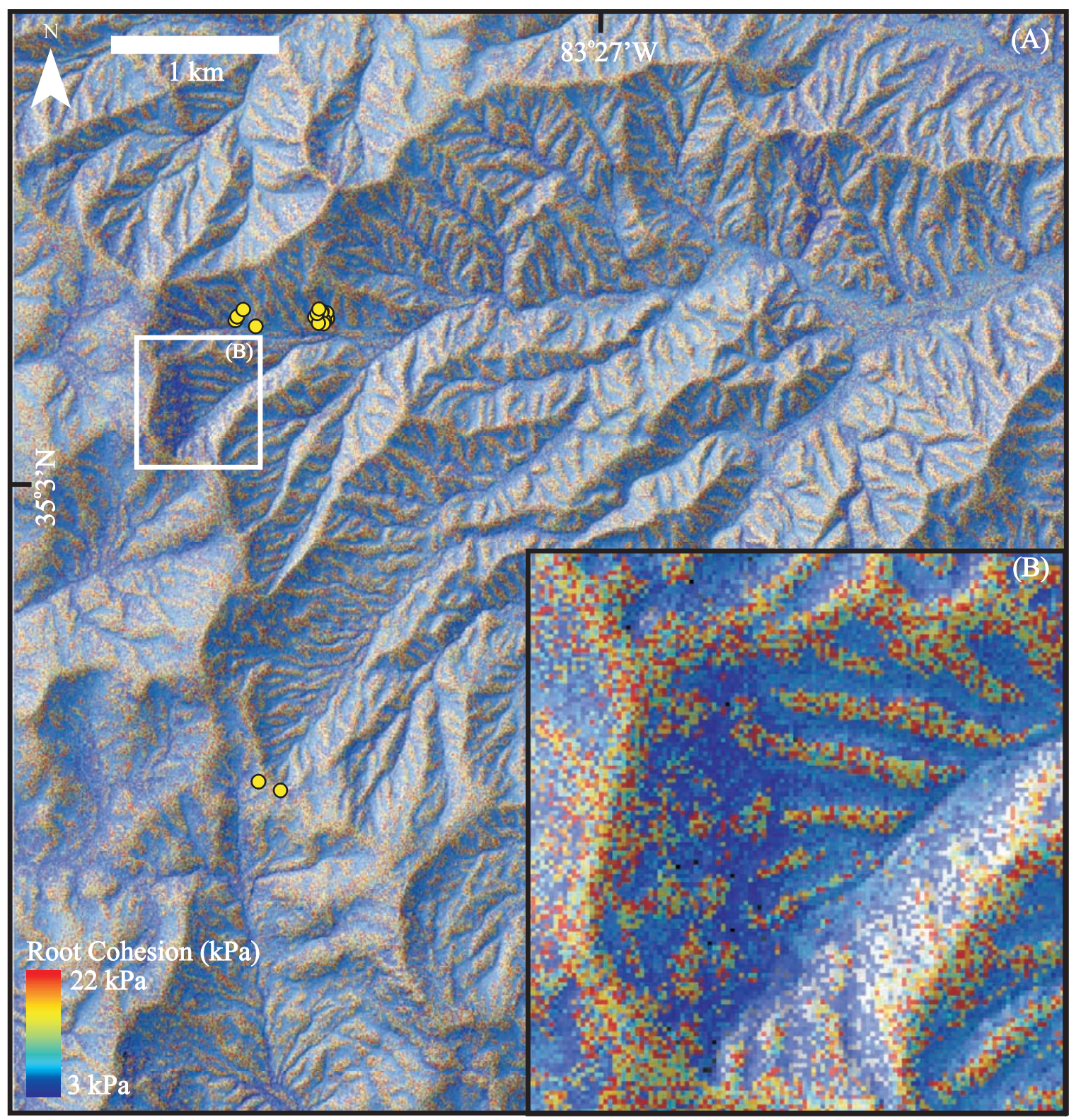

Figure 7. Spatial model of the distribution of root cohesion across Coweeta Hydrological Laboratory. Yellow dots represent the locations of pits and trenches sampled in this study. The model shows the difference in strength between nose and hollow locations.

These differences in gross soil structure may affect the available soil moisture for root growth. Many of the properties that affect soil transmissivity are also important controls on the soil shear strength. We measured the bulk soil shear strength using the triaxial method and tested whether there were significant differences in shear strength between different soil horizons using a vane shear. In all pits there was no consistent trend in measured shear strength with depth or in the mean value of shear strength as a function of topographic position or species (Figure 2). All of the pits showed a large horizontal variation in soil strength, denoted by the high standard deviation in each point. These large standard deviations were consistent with using a vane apparatus that was up to half the size of the weathered clasts found in the soil. Vane shear measurements provide a crude field estimate of the soil shear strength, more detailed direct shear measure- ments would be necessary to confirm this relationship. It is likely that there is some variability in soil shear strength, particularly between the soil and saprolite, which does not appear to be captured using this shear vane method.

\subsection{Topographic Controls on the Distribution of Tree Roots}

[38] Our data suggest that vertical root distributions vary as a function of landscape position, most likely reflecting differences in water availability and soil nutrients. Roots in hollow soils, which have thick A horizons and higher soil water contents, can draw essential nutrients from a greater proportion of the soil column. The result is that fine roots, which function primarily for nutrient uptake [Davis et al., 2004] are distributed more evenly than in nose soils. Noses, which have a high concentration of nutrients close to the 
surface and a lower soil moisture or nutrient content in the $\mathrm{B}$ horizon, contain fewer fine roots at depth. In cases where nose soils had a distinctive saprolite, there was also an increase in the number of roots at this layer, possibly related to increased water flowing at the soil-saprolite boundary.

[39] One limitation of our approach is that the distribution of roots is measured across a two-dimensional surface. While this is a useful and valid methodology given that slope failures occur along relatively planar surfaces $[W u$, 1995], the spatial distribution of root strength varies as a function of the three dimensional structure of the root mass [Dupuy et al., 2005; Reubens et al., 2007]. This structure can be calculated by excavating the roots with high pressure water [McGinty, 1976; Watson and O'Loughlin, 1985, 1990] or air [Norris, 2005; Reubens et al., 2007]. Only recently have measurements of root distributions in three dimensions been used to test how roots affect failure planes of different orientations [Danjon et al., 2007]. Alternatively, rule-based models of root growth have provided a useful method for testing the role of roots in preventing uprooting failures [Dupuy et al., 2005; Reubens et al., 2007]. A root growth model that varied rooting architecture showed that strains associated with tree overturning were distributed at relatively shallow depths within the soil column. These differences in rooting distribution and architecture were more effective for different soils, with tap roots having the most resistance to failure in sandy soils [Dupuy et al., 2005]. These studies of the growth and development of a three-dimensional rooting structure provide a theoretical and empirical setting for understanding length-diameter relationships between roots, which is particularly important when trying to convert ubiquitous root biomass measurements into root cohesions.

\subsection{Topographic Controls on Root Strength}

[40] Within species, we found that roots from trees on noses could sustain a greater tensile force before failing compared to those found in hollows (Figure 5). This pattern appeared to hold for different tree species, suggesting a topographically mediated physiologic control of root tensile strength. Compared to herbaceous roots, woody roots are perennial and contain secondary xylem tissue as the principal water-transporting tissue. Two major trends emerged from our measurements of cellulose content in roots: the first was an increase in cellulose content with decreasing diameter; the second was an increase in cellulose content with topographic position.

[41] Root cellulose content increased with decreasing diameter. Our results are consistent with Genet et al. [2005] who showed nonlinear increases in the tensile strength of small diameter roots concomitant with increases in cellulose content. Within xylem cell walls, cellulose microfibrils impart tensile strength, while lignin encasing the microfibrils adds rigidity to cell walls. Larger roots may have a lower percentage cellulose compared to smaller roots because of their more important role in storing carbohydrates [Guo et al., 2004] and waste compounds (i.e., resins).

[42] Within any root diameter class, roots in nose positions had a higher cellulose content and greater strength compared to roots in hollows. This is consistent with a study that noted the compressive strength and density of stem wood increased as the volumetric water content of the topsoil decrease [Barij et al., 2007]. Barij et al. [2007] showed that stem wood density and compressive strength decreased with a theoretical hydraulic conductivity. Our data show an increase in cellulose content (and tensile strength) with decreasing relative soil moisture suggesting a relationship between soil water potential and the hydraulic architecture of root tissue. For example, plants growing in soils with lower water potentials typically have thicker xylem cell walls relative to the xylem cell lumen diameter [Hacke et al., 2001] compared to plants growing in soils with higher water potentials. This hydraulic adjustment has been documented to occur across a wide range of species and woody plant life forms and is directly linked with the plant's ability to maintain a reliable supply of water to the leaves [Hacke et al., 2001]. Alternatively, higher cellulose content in root tissues on nose positions compared to hollow positions could also result if these roots have greater gravitational or mechanical stress placed on roots. Nose sites receive a higher amount of wind and are often steeper than hollows, which enhances the likelihood of a overturning [Dupuy et al., 2005]. In hardwood species, xylem tissue under greater gravitational or mechanical stress has a lower lignin to cellulose ratio compared to nonstressed xylem. This phenomenon, termed tension wood, generalizes across many angiosperm tree species and results in localized accumulation of cellulose which imparts higher tensile strengths, however may not be important for small roots [Bamber, 2001; Timell, 1967]. Thus roots on noses are likely to be stronger to resist the increased tensile force and may have an increase in the amount of cellulose as a result. However, as root anchorage is thought to be primarily controlled by the largest roots, which have a high frictional coupling to the soil mass [Anderson et al., 1989; Ennos, 1990] smaller roots are less likely to be subjected to high stresses that increase cellulose content. Although cellulose content of large roots tended to converge in hollow and nose positions in our data set, which would confirm this reasoning, this pattern was not statistically significant.

[43] Recently a number of papers have suggested that small roots provided proportionally greater cohesive strength than larger roots [Bischetti et al., 2005; De Baets et al., 2008; Genet et al., 2005; Mattia et al., 2005]. This is based primarily on plots of root tensile strength versus diameter, which tends to follow a power law $\left(t_{\mathrm{ri}}=\alpha \cdot d_{\mathrm{ri}}^{\beta}\right)$. For our data, which contain a large number of root tensile force estimates for small root diameters, a power law fit explained very little of the variance in the tensile strength ( $\mathrm{R}^{2}$ values were less than 0.35 , see auxiliary material). The two-dimensional stability approach favored by $W u$ et al. [1979] and applied in many of these studies [e.g., Bischetti et al., 2005; De Baets et al., 2008], assumes that roots only break along a single failure plane, thus making the total root cohesive strength in the failure plane simply a function of the sum of the root tensile force divided by the total area of the failure plane (equation (2)). Root tensile force increased with the square of diameter (Figure 4) [e.g., Hathaway and Penny, 1975; Schmidt et al., 2001], so larger roots provide more strength to the soil column relative to the smaller roots. Thus detailed characterization of this root tensile force curve provides the most reliable data from which to measure the root cohesion.

[44] Topography provides a primary control on the distribution of soil water in landslide-prone terrain [Montgomery 
and Dietrich, 1994; Tague and Band, 2004]. Hollows have a higher soil water potential than noses and are less prone to drought [Hack and Goodlett, 1960]. Compared to noses, trees and shrubs in hollows are more protected from gravitational and mechanical stresses, such as wind. These mechanisms likely contributed to the $20-30 \%$ lower mean cellulose content in samples taken from hollows. This effect appears to be particularly important in the finer roots, where there was up to a $40 \%$ difference in cellulose content with topographic position (Figure 5). Fine roots respond rapidly (annually to seasonally) to changes in environmental variables, so they are especially sensitive to variation in soil water potential [Joslin and Wolfe, 1998; Joslin et al., 2000]. Thus, there may be a feedback between topographic position, seasonality, and root cohesion, where the strength and number of fine roots varies as a function of the precipitation history. This suggests that in particularly rainy years, the number of fine roots will increase, yet they will be weaker than in drier years. However, within the year, in southern Appalachian forests intense tropical precipitation tends to occur in the driest season, when the fine roots are strongest. Because fine roots make up a considerable proportion of the root biomass (up to 95\%), these seasonal dynamics may play an important role in controlling root cohesion.

\subsection{Controls on Root Cohesion}

[45] Our depth-averaged root cohesion values measured using the $\mathrm{Wu}$ method (3.4-22.4 $\mathrm{kPa})$, are consistent with other literature-based measurements of root cohesion [e.g., Cammeraat et al., 2005; O'Loughlin and Ziemer, 1982; Pollen and Simon, 2005; Riestenberg and Sovonick-Dunford, 1983; Waldron, 1977; Wu, 1984a; Wu, 1984b; Wu et al., 1979; Ziemer, 1981], yet are considerably lower than estimates for switchgrass (Panicum virgatum) $(50-54 \mathrm{kPa})$ [Pollen and Simon, 2005] and natural Oregon Coast Range forests (composed predominantly of Douglas Fir (Pseudotsuga menziesii), $58-151 \mathrm{kPa}$ ) [Schmidt et al., 2001]. Our FBM estimates are $30-70 \%$ lower than the $\mathrm{Wu}$ estimates, consistent with sensitivity tests of the original model [Pollen and Simon, 2005]. Root cohesion varied primarily with the number of roots (Figures 3 and 6). This is because there were relatively few large, strong roots in our profiles, so most of the root cohesive strength was controlled by the abundant small roots. However, where large roots occurred they increased the modeled root cohesion considerably (Figure 6). This was due to the root area versus root tensile force regression coefficients that we used in the modeled cohesion estimates, which produced relatively large tensile forces for the large roots. However, observations of the distribution of roots in landslides suggest that these large roots tend to pull out of the soil rather than contribute directly to the cohesive strength of the soil [Schmidt et al., 2001] This observation is supported by experiments on leek (Allium porrum) seedling roots, which showed that when a tensile (uprooting) force is applied to a root system via the stem then the initial load is distributed among the largest roots, which break the root-soil bond [Ennos, 1990]. Failure of this bond continues until a critical length is reached where the shear strength of the bond is equal to the tensile strength of the root. Thus there is likely to be an optimum root diameter that represents the balance between small, weak roots and large roots that are susceptible to pulling out [Pollen, 2007].
Quantifying the role of the unbroken roots in providing strength to soils requires a better understanding of the length-diameter relationships of root systems.

\subsection{Spatial Modeling of Root Cohesion}

[46] Despite the complexity of the controls on root cohesive strength discussed above, two important trends emerged that allowed us to model the distribution of root cohesion across the drainage basin. The first was the uniformity in root tensile force measurements of different hardwood species. The second was the consistency in root tensile forces and depth distribution of roots as a function of topographic position. This suggests that for a southern Appalachian hardwood forest, it may be possible to estimate the root cohesion on the basis of differences in landscape curvature.

[47] Other attempts to model the spatial distribution of root cohesion have concentrated on differences in strength at the single tree scale [Roering et al., 2003; Sakals and Sidle, 2004] or have just estimated a uniform distribution of root cohesion across a landscape [Pack et al., 1998]. Roering et al. [2003] suggested debris flows initiated in areas of low root cohesion between trees, and produced a simple method for mapping of the distribution of trees and their canopies in hollows to quantify the landslide potential. Sakals and Sidle [2004] used empirical relationships between tree age and root distribution to create a root influence radius, which represented $99 \%$ of the root density for a particular tree. They then created a spatial model of root cohesion in which the influences of individual tree roots were explicitly modeled and the evolution of root cohesion was calculated for different forest management strategies [Sakals and Sidle, 2004]. Both these studies highlight the importance of lateral variability in cohesive strength. However, we are unable to model these single tree effects because of the grid spacing $(6 \mathrm{~m})$ of our model. Therefore our model assumes that most of the lateral heterogeneity at that scale is related to topographic position rather than the influence of individual plants.

[48] Our simple, bimodal root strength model represents a first attempt at quantifying the spatial distribution of root cohesion as a function of topography (Figure 7). The coupling of root physiology with topographically controlled parameters such as soil moisture, nutrient content (as shown by variations in A horizon thickness), and anchorage needs means that a physically meaningful spatial model is possible on the basis of topography. Further work is required to quantify the relationship between soil water potential and cellulose content of roots, but it may provide a physically based framework for estimating root tensile force on hillslopes without the need for detailed root strength measurements. When combined with the extensive literature on root distributions for different biomes and plant types [Jackson et al., 1996], it may be possible to quantify root cohesion in data-poor areas. This is particularly important in the southern Appalachians where large historic landsliding and flooding events have occurred in heavily forested areas where little information exists about the soil and rooting conditions.

\subsection{Possible Effects of Expansion of Rhododendron Maximum}

[49] Fire suppression, which has enabled expansion of Rhododendron maximum, a fire-sensitive, evergreen erica- 
ceous, woody shrub, could have important implications for slope stability in the southern Appalachians. $R$. maximum is a key species because it has a particularly low root cohesive strength and has low stomatal conductance per unit leaf area [Nilsen, 1985], which when coupled with a low leaf area [Nilsen, 1986] leads to low transpiration (C. R. Ford and J. M. Vose, unpublished data, 2007). R. maximum reduces the amount of light available to the canopy floor and alters the nitrogen cycle such that tree seedlings are less likely to grow [Clinton and Vose, 1996; Nilsen et al., 2001; Phillips and Murdy, 1985; Wurzburger and Hendrick, 2007, 2009]. As a result, advanced tree regeneration is not present to replace canopy openings created when overstory trees die. The growth of $R$. maximum at the expense of larger trees causes considerable changes in the root cohesion. Our data show that $R$. maximum roots are considerably weaker than any of the tree species that we measured (Figure 4 and Table 2). These weak roots are found shallowly within the soil profile, with much of the root biomass located in the $\mathrm{O}$ horizon. The result is that hollows containing significant proportions of $R$. maximum have a lower root cohesive strength than those containing large trees and this cohesive strength is found within the top few centimeters of soil. When coupled with increased soil moisture resulting from low transpiration rates and low soil evaporative energy, it suggests that $R$. maximum may be a key species affecting landslide initiation in the southern Appalachians. Landslide events during 2004 were commonly initiated in $R$. maximum thickets, including the only landslide to occur in the Coweeta drainage basin. The largest landslide initiation area $\left(\sim 10,000 \mathrm{~m}^{2}\right)$ from the 2004 event, the Peeks Creeks debris flow, also formed in a $R$. maximum thicket [Wooten et al., 2007].

\section{Conclusions}

[50] We present a data set of root tensile force and root distributions for ten southern Appalachian tree and woody shrub species in an attempt to constrain the spatial variability of root cohesion in these landslide-prone forests. Root tensile forces were consistent among most of the tree species measured. However, trees that were found in hollows had consistently weaker roots, possibly related to the difference in root structural chemistry associated with soil water potential at the different topographic locations. The number of roots declined exponentially with soil depth, likely related to the availability of nutrients close to the surface. In combination, these factors lead to a higher mean root cohesive strength on noses than in hollows. These results highlight an important feedback between root physiology, shallow slope hydrology, and root cohesive strength. Quantifiable differences in soil moisture and texture in hollows and noses allow constraint of the spatial distribution of root cohesion without the need for detailed field measurements of root properties. These results highlight how the landscape and forest ecosystem have coevolved and the potential sensitivity of this feedback to unintended effects of forest management, particularly $R$. maximum expansion.

[51] Acknowledgments. Funding was provided by a USDA Forest Service cooperative agreement to Band. Many thanks to Daniel Band and Jenny Riker, whose mastery of pick, shovel, and paint brush were invaluable in the field. Many thanks also to Rick Wooten and his crew of dedicated landslide mappers at the North Carolina Geological Survey for valuable discussions, field trips, and access to their landslide maps. The North Carolina Department of Transportation ran our triaxial shear tests. Many thanks for detailed revisions by Kevin Schmidt and two anonymous reviewers that improved the manuscript significantly.

\section{References}

Abernethy, B., and I. D. Rutherfurd (2001), The distribution and strength of Riparian tree roots in relation to riverbank reinforcement, Hydrol. Processes, 15, 63-79, doi:10.1002/hyp.152.

Addington, R. N., L. A. Donovan, R. J. Mitchell, J. M. Vose, S. D. Pecot, S. B. Jack, U. G. Hacke, J. S. Sperry, and R. Oren (2006), Adjustments in hydraulic architecture of Pinus palustris maintain similar stomatal conductance in xeric and mesic habitats, Plant Cell Environ., 29, 535-545, doi:10.1111/j.1365-3040.2005.01430.x.

Amaranthus, M. P., R. M. Rice, N. R. Barr, and R. R. Ziemer (1985), Logging and forest roads related to increased debris slides in southwestern Oregon, J. For., 83(4), 229-233.

Anderson, C. J., M. P. Coutts, R. M. Ritchie, and D. J. Campbell (1989), Root extraction force measurements for Sitka Spruce, Forestry, 62(2), 127-137, doi:10.1093/forestry/62.2.127.

Bamber, R. K. (2001), A general theory for the origin of growth stresses in reaction wood: How trees stay upright, IAWA J., 22, 205-212.

Barij, N., A. Stokes, T. Bogaard, and R. van Beek (2007), Does growing on a slope affect tree xylem structure and water relations?, Tree Physiol., 27, $757-764$

Bischetti, G. B., E. A. Chiaradia, T. Simonato, B. Speziali, B. Vitali, P. Vullo, and A. Zocco (2005), Root strength and root area ratio of forest species in Lombardy (northern Italy), Plant Soil, 278, 11-22, doi:10.1007/ s11104-005-0605-4.

Bolstad, P. V., J. M. Vose, and S. G. McNulty (2001), Forest productivity, leaf area, and terrain in southern Appalachian deciduous forests, For. Sci., 47(3), 419-427.

Brown, G. W., and J. T. Krygier (1971), Clear-cut logging and sediment production in the Oregon Coast Range, Water Resour. Res., 7(5), 1189-1198, doi:10.1029/WR007i005p01189.

Buchanan, P., and K. W. Savigny (1990), Factors controlling debris avalanche initiation, Can. Geotech. J., 27(5), 659-675, doi:10.1139/t90-079. Cammeraat, E., R. Van Beek, and A. Kooijman (2005), Vegetation succession and its consequences for slope stability in SE Spain, Plant Soil, 278, 135-147, doi:10.1007/s11104-005-5893-1.

Clark, G. M. (1987), Debris slide and debris flow historical events in the Appalachians south of the glacial border, Rev. Eng. Geol., 7, 125-138.

Clinton, B. D., and J. M. Vose (1996), Effects of Rhododendron maximum L. on Acer rubrum L. seedling establishment, Castanea, 61(1), 38-45.

Cofie, P., and A. J. Koolen (2001), Test speed and other factors affecting the measurements of tree root properties used in soil reinforcement models, Soil Tillage Res., 63, 51-56, doi:10.1016/S0167-1987(01)00225-2.

Daniels, H. E. (1945), The statistical theory of the strengths of bundles of threads, Proc. R. Soc. London, 283(995), 405-435.

Danjon, F., D. H. Barker, M. Drexhage, and A. Stokes (2007), Using threedimensional plant root architecture in models of shallow slope stability, Ann. Bot., 101, 1281-1293, doi:10.1093/aob/mcm199.

Davis, J. P., B. Haines, D. Coleman, and R. Hendrick (2004), Fine root dynamics along an elevational gradient in the southern Appalachian Mountains, USA, For. Ecol. Manage., 187, 19-34, doi:10.1016/ S0378-1127(03)00226-3.

De Baets, S., J. Poesen, B. Reubens, K. Wemans, J. De Baerdemaeker, and B. Muys (2008), Root tensile strength and root distribution of typical mediterranean plant species and their contribution to soil shear strength, Plant Soil, 305, 207-226, doi:10.1007/s11104-008-9553-0.

Dietrich, W. E., R. Reiss, M.-L. Hsu, and D. R. Montgomery (1995), A process-based model for colluvial soil depth and shallow landsliding using digital elevation data, Hydrol. Processes, 9, 383-400, doi:10.1002/ hyp. 3360090311.

Douglass, J. E., and M. D. Hoover (1988), History of Coweeta, in Forest Hydrology and Ecology at Coweeta, edited by W. T. Swank and D. A. Crossley, pp. 17-31, Springer, New York.

Dowdy, S., and S. Wearden (1991), The analysis of variance model, in Statistics for Research, edited by V. Barnett et al., pp. 339-367, John Wiley, New York.

Dupuy, L., T. Fourcaud, and A. Stokes (2005), A numerical investigation into the influence of soil type and root architecture on tree anchorage, Plant Soil, 278, 119-134, doi:10.1007/s11104-005-7577-2.

Elliott, K. J., and D. Hewitt (1997), Forest species diversity in upper elevation hardwood forests in the southern Appalachian Mountains, Castanea, 62(1), 32-42.

Elliott, K. J., and W. T. Swank (2008), Long-term changes in forest composition and diversity following early logging (1919-1923) and the decline of American chestnut (Castanea dentata), Plant Ecol., 197, 155-172, doi:10.1007/s11258-007-9352-3. 
Ennos, A. R. (1990), The anchorage of Leek seedlings: The effect of root length and soil strength, Ann. Bot., 65, 409-416.

Genet, M., A. Stokes, F. Salin, S. B. Mickovski, T. Fourcaud, J.-F. Dumail, and $\mathrm{R}$. van Beek (2005), The influence of cellulose content on tensile strength of tree roots, Plant Soil, 278, 1-9, doi:10.1007/s11104-005-8768-6.

Gerber, M. (2004), Geomorphic Response to Wildfire in the Oregon Coast Range, Univ. of Oreg., Eugene, Oreg.

Guo, D. L., R. J. Mitchell, and J. J. Hendricks (2004), Fine root branch orders respond differentially to carbon source-sink manipulations in a Longleaf Pine forest, Oecologia, 140, 450-457, doi:10.1007/s00442004-1596-1.

Hack, J. T., and J. C. Goodlett (1960), Geomorphology and forest ecology of a mountain region in the central Appalachians, U.S. Geol. Surv. Prof Pap., 347, 1-66.

Hacke, U. G., J. S. Sperry, W. T. Pockman, S. D. Davis, and K. A. McCulloch (2001), Trends in wood density and structure are linked to prevention of xylem implosion by negative pressure, Oecologia, 126, 457-461, doi:10.1007/s004420100628.

Hathaway, R. L., and D. Penny (1975), Root strength in some Populus and Salix clones, N. Z. J. Bot., 13, 333-344

Iverson, R. M., M. E. Reid, and R. G. LaHusen (1997), Debris-flow mobilization from landslides, Annu. Rev. Earth Planet. Sci., 25, 85-138, doi:10.1146/annurev.earth.25.1.85.

Jackson, R. B., J. Canadell, J. R. Ehleringer, H. A. Mooney, O. E. Sala, and E. D. Schulze (1996), A global analysis of root distributions for terrestrial biomes, Oecologia, 108, 389-411, doi:10.1007/BF00333714.

Joslin, J. D., and M. H. Wolfe (1998), Impacts of water input manipulations on fine root production and mortality in a mature hardwood forest, Plant Soil, 204, 165-174, doi:10.1023/A:1004352008490.

Joslin, J. D., M. H. Wolfe, and P. J. Hanson (2000), Effects of altered water regimes on forest root systems, New Phytol., 147, 117-129, doi:10.1046/ j.1469-8137.2000.00692.x.

Kochenderfer, J. N. (1973), Root distribution under some forest types native to West Virginia, Ecology, 54(2), 445-448, doi:10.2307/1934355.

Lambe, P. C., and A. H. Riad (1990), Determination of shear strength for design of cut slopes in partly weathered rock and saprolite, in Federal Highways Administration Report, pp. 1-453, Cent. for Transp. Eng. Stud., Raleigh, N. C.

Latham, R. S., R. M. Wooten, and J. C. Reid (2005), Preliminary findings on the September 16, 2004 debris flow at Peeks Creek, Macon County, North Carolina, paper presented at 56th Highway Geology Symposium, N. C. Dep. of Transp., Wilmington, N. C.

Leavitt, S. W., and S. R. Danzer (1993), Methods for batch processes small wood samples to holocellulose for stable-carbon isotope analysis, Anal. Chem., 65, 87-89, doi:10.1021/ac00049a017.

Mattia, C., G. B. Bischetti, and F. Gentile (2005), Biotechnical characteristics of root systems of typical Mediterranean species, Plant Soil, 278 23-32, doi:10.1007/s11104-005-7930-5.

McGinty, D. T. (1976), Comparitive Root and Soil Dynamics on a White Pine Watershed and in the Hardwood Forest in the Coweeta Basin, Univ. of Ga., Athens, Ga.

Mills, K., J. Paul, J. Hinkle, and A. R. Skaugset (2003), Forest practices and mitigation of debris-flow risk in Oregon, USA, in Debris-Flow Hazards Mitigation: Mechanics, Prediction, and Assessment, edited by D. Rickenmann and C. L. Chen, pp. 1197-1207, Millpress, Rotterdam, Netherlands.

Montgomery, D. R., and W. E. Dietrich (1994), A physically based model for the topographic control on shallow landsliding, Water Resour. Res. 30(4), 1153-1171, doi:10.1029/93WR02979.

Montgomery, D. R., K. Schmidt, H. M. Greenburg, and W. E. Dietrich (2000), Forest clearing and regional landsliding, Geology, 28(4), 311-314, doi:10.1130/0091-7613(2000)28<311:FCARL > 2.0.CO;2.

Moore, I. D., R. B. Grayson, and A. R. Landson (1991), Digital terrain modelling: A review of hydrological, geomorphological, and biological applications, Hydrol. Processes, 5, 3-30, doi:10.1002/hyp.3360050103.

Morgan, B. A., G. Iovine, P. Chirico, and G. F. Wieczorek (1999), Inventory of debris flows and floods in the Lovingston and Horseshoe Mountain, VA, $7.5^{\prime}$ Quadrangles, from the August 19/20, 1969, Storm in Nelson County, Virginia, U.S. Geol. Surv. Open File Rep., 99-518, 1-8.

Nilsen, E. T. (1985), Seasonal and diurnal leaf movements of Rhododendron maximum $L$. in contrasting irradiance environments, Oecologia, 65 , 296-302, doi:10.1007/BF00379233.

Nilsen, E. T. (1986), Quantitative phenology and leaf survivorship of Rhododendron maximum in contrasting irradiance environments of the southern Appalachian Mountains, Am. J. Bot., 73(6), 822-831, doi: $10.2307 / 2444293$.

Nilsen, E. T., B. D. Clinton, T. T. Lei, O. K. Miller, S. W. Semones, and J. F. Walker (2001), Does Rhododendron maximum L. (Ericaceae) reduce the availability of resources above and belowground for canopy tree seedlings?, Am. Midland Nat., 145, 325-343, doi:10.1674/0003-0031 (2001)145[0325:DRMLER]2.0.CO;2.

Norris, J. E. (2005), Root reinforcement by Hawthorn and Oak roots on a highway cut-slope in southern England, Plant Soil, 278, doi:10.1007/ s11104-005-1301-0.

O'Loughlin, C., and R. R. Ziemer (1982), The importance of root strength and deterioration rates upon edaphic stability in steepland forests, in Proceedings of I.U.F.R.O. Workshop P.1.07-00 Ecology of Subalpine Ecosystems as a Key to Management. 2-3 August 1982, Corvallis, Oregon, pp. 70-78, Oreg State Univ., Corvallis, Oreg.

Pack, R. T., D. G. Tarboton, and C. N. Goodwin (1998), The SINMAP approach to terrain stability mapping, paper presented at 8th Congress, Int. Assoc. of Eng. Geol. and the Environ., Vancouver, B. C., Canada.

Peek, M. S., E. Russek-Cohen, D. A. Wait, and I. N. Forseth (2002), Physiological response curve analysis using nonlinear mixed models, Oecologia, 132(2), 175-180, doi:10.1007/s00442-002-0954-0.

Phillips, D. L., and W. H. Murdy (1985), Effects of Rhododendron (Rhododendron maximum L.) on regeneration of southern Appalachian Hardwoods, For. Sci., 31(1), 226-233.

Pollen, N. (2007), Temporal and spatial variability in root reinforcement of streambanks: Accounting for soil shear strength and moisture, Catena, 69, 197-205, doi:10.1016/j.catena.2006.05.004

Pollen, N., and A. Simon (2005), Estimating the mechanical effects of riparian vegetation on stream bank stability using a fiber bundle model, Water Resour. Res., 41, W07025, doi:10.1029/2004WR003801.

Pollen, N., A. Simon, and A. J. C. Collison (2004), Advances in assessing the mechanical and hydrologic effects of riparian vegetation on streambank stability, in Riparian Vegetation and Fluvial Geomorphology, edited by S. Bennett and A. Simon, pp. 125-139, AGU, Washington, D. C.

Reubens, B., J. Poesen, F. Danjon, G. Geudens, and B. Muys (2007), The role of fine and coarse roots in shallow slope stability and soil erosion control with a focus on root system architecture: A review, Trees, 21, 385-402, doi:10.1007/s00468-007-0132-4

Riestenberg, M. M., and S. Sovonick-Dunford (1983), The role of woody vegetation in stabilizing slopes in the Cincinatti area, Ohio, Geol. Soc. Am. Bull., 15, 3-45.

Roering, J. J., K. M. Schmidt, J. D. Stock, W. E. Dietrich, and D. R. Montgomery (2003), Shallow landsliding, root reinforcement, and the spatial distribution of trees in the Oregon Coast Range, Can. Geotech. $J ., 40,237-253$, doi:10.1139/t02-113.

Sakai, Y., M. Takahashi, and N. Tanaka (2007), Root biomass and distribution of a Picea-Abies stand and a Larix-Betula stand in pumiceous Entisols in Japan, J. For. Res., 12, 120-125, doi:10.1007/s10310-006-0270-3.

Sakals, M. E., and R. C. Sidle (2004), A spatial and temporal model of root cohesion in forest soils, Can. J. For. Res., 34, 950-958, doi:10.1139/ $\mathrm{x} 03-268$.

Schmidt, K., J. J. Roering, J. D. Stock, W. E. Dietrich, D. R. Montgomery, and T. Schaub (2001), The variability of root cohesion as an influence on shallow landslide susceptibility in the Oregon Coast Range, Can. Geotech. J., 38(5), 995-1024, doi:10.1139/cgj-38-5-995.

Selby, M. J. (1993), Hillslope Materials and Processes, 451 pp., Oxford Univ. Press, Oxford, U. K

Stock, J., D. R. Montgomery, B. D. Collins, W. E. Dietrich, and L. Sklar (2005), Field measurements of incision rates following bedrock exposure Implications for process controls on the long profiles of valleys cut by rivers and debris flows, Geol. Soc. Am. Bull., 117(1-2), 174-194, doi:10.1130/B25560.1.

Stone, E. L., and P. J. Kalisz (1991), On the maximum extent of tree roots, For. Ecol. Manage., 46, 59-102, doi:10.1016/0378-1127(91)90245-Q.

Swift, L. W., G. B. Cunningham, and J. E. Douglass (1988), Climatology and hydrology, in Forest Hydrology and Ecology at Coweeta, edited by W. T. Swank and D. A. Crossley, pp. 35-55, Springer, New York.

Tague, C. L., and L. E. Band (2004), RHESSys: Regional Hydro-Ecologic Simulation System-An object-oriented approach to spatially distributed modeling of carbon, water, and nutrient cycling, Earth Interact., 8, 1-42, doi:10.1175/1087-3562(2004)8<1:RRHSSO $>2.0 . \mathrm{CO} ; 2$.

Timell, T. E. (1967), Recent progress in the chemistry of wood hemicelluloses, Wood Sci. Technol., 1, 45-70, doi:10.1007/BF00592255.

Waldron, L. J. (1977), The shear resistance of root-permeated homogeneous and stratified soil, Soil Sci. Soc. Am. J., 41, 843-849.

Watson, A., C. Phillips, and M. Marden (1999), Root strength, growth, and rates of decay: Root reinforcement changes of two tree species and their contribution to slope stability, Plant Soil, 217, 39-47, doi:10.1023/ A: 1004682509514.

Watson, A. J., and C. O'Loughlin (1985), Morphology, strength, and biomass of Manuka roots and their influence on slope stability, N. Z. J. For Sci., 15(3), 337-348.

Watson, A. J., and C. O'Loughlin (1990), Structural root morphology and biomass of three age-classes of Pinus Radiata, N. Z. J. For. Sci., 20(1), 97-110. 
Wieczorek, G. F., G. S. Mossa, and B. A. Morgan (2004), Regional debrisflow distribution and preliminary risk assessment from severe storm events in the Appalachian Blue Ridge Province, USA, Landslides, 1, 53-59, doi:10.1007/s10346-003-0003-z.

Witt, A. C. (2005), A brief history of debris flow occurrence in the French Broad River watershed, western North Carolina, N. C. Geogr., 13, 58-82.

Wooten, R. M., R. S. Latham, A. C. Witt, K. A. Gillon, T. J. Douglas, S. J. Fuemmeler, J. B. Bauer, and J. C. Reid (2007), Landslide hazards and landslide hazard mapping in North Carolina, in 1st North American Landslide Conference, edited by V. R. Schaefer, R. L. Schuster, and A. K. Turner, pp. 458-471, Assoc. of Environ. and Eng. Geol., Vail, Colo.

Wu, T. H. (1984a), Effect of vegetation on slope stability, in Soil Reinforcement and Moisture Effects on Slope Stability, pp. 37-46, Transp. Res. Board, Washington, D. C.

Wu, T. H. (1984b), Soil movements on permafrost slopes near Fairbanks, Alaska, Can. Geotech. J., 21, 699-709, doi:10.1139/t84-076.

Wu, T. H. (1995), Slope stabilization, in Slope Stabilization and Erosion Control: A Bioengineering Approach, edited by R. P. C. Morgan and R. J. Rickson, pp. 221-264, E and FN Spon, London.

Wu, T. H., W. P. McKinnell III, and D. N. Swanston (1979), Strength of tree roots and landslides on Prince of Wales Island, Alaska, Can. Geotech. J., 16, 19-34, doi:10.1139/t79-003.

Wu, T. H., P. E. Beal, and C. Lan (1988a), In-situ shear test of soil-root systems, J. Geotech. Eng., 114(12), 1376-1394, doi:10.1061/ (ASCE)0733-9410(1988)114:12(1376)

Wu, T. H., R. M. McOmber, R. T. Erb, and P. E. Beal (1988b), Study of soil-root interaction, J. Geotech. Eng., 114(12), 1351-1375, doi:10.1061/ (ASCE)0733-9410(1988)114:12(1351)
Wurzburger, N., and R. Hendrick (2007), Rhododendron thickets alter $\mathrm{N}$ cycling and soil extracellular enzyme activity in southern Appalachian hardwood forests, Pedobiologia, 50, 563-576, doi:10.1016/j.pedobi. 2006.10.001.

Wurzburger, N., and R. L. Hendrick (2009), Plant litter chemistry and mycorrhizal roots promote a nitrogen feedback in a temperate forest, J. Ecol., 97, 528-536.

Zar, J. H. (1984), Biostatistical Analysis, 2nd ed., 718 pp., Prentice Hall, Englewood Cliffs, N. J.

Ziemer, R. R. (1981), Roots and the stability of forested slopes, in Proceedings of the International Symposium on Erosion and Sediment Transport in Pacific Rim Steeplands, edited by T. R. H. Davies and A. J. Pearce, pp. 343-361, N. Z. Int. Assoc. of Hydrol. Sci., Christchurch, New Zealand

L. E. Band and T. Hwang, Department of Geography, University of North Carolina at Chapel Hill, Saunders Hall, Campus Box 3220, Chapel Hill, NC 27599-3220, USA.

C. R. Ford and J. M. Vose, Coweeta Hydrologic Laboratory, Southern Research Station, USDA Forest Service, 3160 Coweeta Lab Road, Otto, NC 28763, USA.

T. C. Hales, School of Earth and Ocean Sciences, Cardiff University, Main Building, Park Place, Cardiff CF10 3YE, UK. (halest@cardiff.ac.uk) 